\title{
Medium-chain fatty acids modulate myocardial function via a cardiac odorant receptor
}

\author{
Nikolina Jovancevic ${ }^{1} \cdot$ A. Dendorfer ${ }^{2,6} \cdot$ M. Matzkies $^{3} \cdot$ M. Kovarova ${ }^{5}$. \\ J. C. Heckmann ${ }^{1} \cdot$ M. Osterloh ${ }^{1} \cdot$ M. Boehm ${ }^{1}$ L. Weber ${ }^{1}$. F. Nguemo ${ }^{3}$. \\ J. Semmler ${ }^{3} \cdot$ J. Hescheler ${ }^{3} \cdot$ H. Milting ${ }^{4} \cdot$ E. Schleicher ${ }^{5} \cdot$ L. Gelis ${ }^{1}$. \\ H. Hatt ${ }^{1}$
}

Received: 29 April 2016/ Accepted: 3 January 2017/Published online: 23 January 2017

(c) The Author(s) 2017. This article is published with open access at Springerlink.com

\begin{abstract}
Several studies have demonstrated the expression of odorant receptors (OR) in various human tissues and their involvement in different physiological and pathophysiological processes. However, the functional role of ORs in the human heart is still unclear. Here, we firstly report the functional characterization of an $\mathrm{OR}$ in the human heart. Initial next-generation sequencing analysis revealed the OR expression pattern in the adult and fetal human heart and identified the fatty acid-sensing OR51E1 as the most highly expressed OR in both cardiac development stages. An extensive characterization of the OR51E1 ligand profile by luciferase reporter gene activation assay identified 2-ethylhexanoic acid as a receptor
\end{abstract}

L. Gelis and H. Hatt are equally contributing authors.

Electronic supplementary material The online version of this article (doi:10.1007/s00395-017-0600-y) contains supplementary material, which is available to authorized users.

Nikolina Jovancevic

Nikolina.Jovancevic@ rub.de

1 Department of Cell Physiology, Ruhr-University Bochum, 44801 Bochum, Germany

2 Walter Brendel Centre of Experimental Medicine, LudwigMaximilians-University, 80336 Munich, Germany

3 Institute for Neurophysiology, University of Cologne, 50931 Cologne, Germany

4 Erich and Hanna Klessmann Institute, Clinic for Thoracic and Cardiovascular Surgery, Heart and Diabetes Center NRW, Ruhr-University Bochum, 32545 Bad Oeynhausen, Germany

5 Division of Pathobiochemistry and Clinical Chemistry, University of Tuebingen, 72076 Tuebingen, Germany

6 DZHK (German Center for Cardiovascular Research), Partner Site Munich Heart Alliance, Munich, Germany antagonist and various structurally related fatty acids as novel OR51E1 ligands, some of which were detected at receptor-activating concentrations in plasma and epicardial adipose tissue. Functional investigation of the endogenous receptor was carried out by $\mathrm{Ca}^{2+}$ imaging of human stem cell-derived cardiomyocytes. Application of OR51E1 ligands induced negative chronotropic effects that depended on activation of the OR. OR51E1 activation also provoked a negative inotropic action in cardiac trabeculae and slice preparations of human explanted ventricles. These findings indicate that OR51E1 may play a role as metabolic regulator of cardiac function.

Keywords Olfactory receptor - Calcium transients .

Negative chronotropic effect - Negative inotropic effect . Medium-chain fatty acids

\section{Introduction}

Transmembrane signal transduction by membrane receptor proteins enables a cell to convert an extracellular signal into cellular responses. Many important cell recognition and communication processes are mediated by a superfamily of transmembrane proteins, the $\mathrm{G}$ protein-coupled receptors (GPCRs). GPCRs play a prominent role in sensing extracellular signals, which cover a broad spectrum from physical to chemical stimuli, e.g., transmitters, hormones or ligands for taste and smell. The significance of these receptors is reflected by the fact that more than $60 \%$ of all commercially available drugs target a GPCR (more than half of all GPCRs are orphan receptors), including pharmaceuticals for cardiovascular diseases such as hypertension, arrhythmias and heart failure [20, 76]. Although cardiovascular diseases remain the leading cause of death worldwide, the majority of 
GPCR modulating cardiovascular drugs exert their function by targeting only the adrenergic and angiotensin GPCR signaling pathways [30, 37]. It is likely, however, that as yet uncharacterized cardiac GPCRs offer opportunities for the development of novel therapies for heart diseases. A recently performed large-scale, next-generation sequencing analysis revealed mRNA expression of a subset of "non-classical" GPCRs, e.g., chemosensory receptors such as taste receptors and odorant receptors (ORs), in the human heart [28]. The superfamily of OR genes was initially identified in the olfactory epithelium of rat as mediators of olfactory chemosensation [11]. Nevertheless, a number of human genes have been classified as OR based on sequence similarity and by the presence of certain predicted protein motifs, and they are also expressed in non-olfactory tissues $[4,25,28,36,115]$. Their discovery sparked a controversial discussion about the potential function of such "ectopically expressed" ORs. Many groups have reported mammalian OR expression at the transcript and/or protein level in various healthy as well as pathophysiologically altered tissues such as prostate cancer $[19,25,31,34,70,101$, $105,109,111,115]$.

Because of upregulated expression in cancer cells, the odorant receptors OR51E1 und OR51E2 were previously implicated as tumor biomarkers [19, 101]. Recently, ORs came into the focus of drug development because ectopically expressed ORs were involved in physiological and pathophysiological mechanisms within human tissues, such as the chemotaxis of sperm, the proliferation of prostate cancer and liver cancer cells, the induction of woundhealing, the modulation of hepatic triglyceride metabolism, cytokinesis, apoptosis and the regulation of serotonin secretion [8, 13, 58, 60, 67, 79, 82, 90, 99, 108, 114].

To date, the functional role of ORs in the heart is still unexplained, although OR mRNA expression in the rat heart had already been analyzed during ontogenetic development 20 years ago [23, 26]. Therefore, the aims of the present study were to analyze the cardiac OR expression profile in greater detail, leading to a special focus on the medium-chain fatty acid (MCFA)-sensing OR51E1 receptor. In this study, we characterized its physiological function in the human heart.

\section{Experimental procedures}

\section{Cell culture}

Human embryonic stem cells (hESCs) and human-induced pluripotent stem cells (hIPSCs) were cultured and differentiated into cardiomyocytes.

Spontaneously beating clusters were generated by coculturing the hES cell line HES-2 [77] or the hIPS cell line
Foreskin C1 [112] with inactivated visceral endoderm like cells (END-2) according to Passier et al. [71], with own modifications. Briefly, HES-2 or hiPS colonies were cultivated for 7 days on irradiated CF1 mouse feeder cells under standard conditions (Madison, WI, USA, http:// www.wicell.org), detached with $0.2 \%$ Collagenase IV (w/ v) and distributed into a six-well dish prepared with $\sim 6 \times 10^{5}$ END-2 cells. The differentiation media consisted of DMEM/F12 (+Glutamax) supplemented with $1 \%$ fetal bovine serum, $1 \%$ nonessential amino acids, $0.1 \mathrm{mM}$ beta-mercaptoethanol, $50 \mathrm{U} / \mathrm{ml}$ and $50 \mu \mathrm{g} / \mathrm{ml}$ penicillin and streptomycin. Reagents, unless indicated otherwise, were purchased from Invitrogen (Life Technologies, Carlsbad, CA, USA). From the third week of differentiation on, the medium content of FBS was increased to $2 \%$. Single cardiomyocytes were isolated from the beating clusters by subsequent enzymatic digestion and plated on fibronectin- $(2.5 \mu \mathrm{g} / \mathrm{ml} \mathrm{D}-\mathrm{PBS})$ and gelatin$(0.1 \%$ in D-PBS) coated coverslips for calcium measurements. The use of hESCs in this project was permitted by the Robert Koch Institute, Berlin, Germany (permission number 1710-79-1-4-2-E05). The cell line Foreskin C1 utilized in this study was provided by James A. Thomson (University of Wisconsin, Madison, WI, USA) [112]. hIPSC-derived cardiomyocytes $\left(\mathrm{iCell}^{\circledR}-\mathrm{CMs}\right)$ were purchased from Cellular Dynamics International (Cellular Dynamics International, Madison, Wisconsin, USA) and maintained by the standard protocols. Single cells were plated on the coated coverslips after dissociation according to the manufacturer's guidelines.

Hana3A cell line was kindly provided by Prof. H. Matsunami (Duke University Medical Center, Durham, NC, USA). Hana3A is an HEK293-derived cell line stably expressing RTP1L, RTP2, REEP1 and $\mathrm{G} \alpha_{\text {olf }}$, which supports the robust heterologous expression of ORs [81]. Cells were maintained in DMEM (Gibco ${ }^{\circledR}$, Life Technologies) supplemented with $10 \%$ FBS and 100 units/ml penicillin and streptomycin. Stem cell-derived cardiomyocytes and Hana3A cells were maintained at $37^{\circ} \mathrm{C}$ in a $5 \% \mathrm{CO}_{2}$ humidified atmosphere.

\section{Human myocardial tissue culture}

Myocardial tissue specimens were procured from patients undergoing heart transplantation. Patients provided informed consent to the scientific use of the explanted tissue, and the study was approved by the local ethics boards of the clinical and the experimental study contributors (Nr. 63-012). Ventricular myocardium was available from heart transplantation and collected at the Heart and Diabetes Center of NRW as $2 \times 2 \mathrm{~cm}^{2}$ transmural biopsies of the left ventricular wall, which were immediately placed in cold $\left(4^{\circ} \mathrm{C}\right)$ BDM containing HEPES buffered salt 
solution. Samples were sent by overnight courier to the Walter Brendel Center, Munich, where 300- $\mu \mathrm{m}$-thick tissue slices were prepared as previously described [7]. Briefly, trimmed tissue blocks measuring approximately $1 \mathrm{~cm}^{3}$ were embedded in $4 \%$ agarose, mounted onto a precision vibratome (Leica VT1200S; Leica, Wetzlar, Germany), and cut along the transversal direction proceeding from the endo- to epicardial layers of the myocardium. Myocardial slices were attached to permeable tissue culture membranes (Millicell-CM, Merck Millipore, Billerica, Massachusetts, USA) and were kept in culture at a tissue-air interface (5\% $\mathrm{CO}_{2}, 20 \% \mathrm{O}_{2}, 37^{\circ} \mathrm{C}$ ) for up to 8 days. The medium (M199 with PS and insulin-transferrin-selen supplements, serumfree; Invitrogen, Carlsbad, CA, USA) was exchanged daily. For the first day of culture, the medium was also supplemented with BDM $(30 \mathrm{mM})$ to support the recovery of tissues from 18 to $28 \mathrm{~h}$ of transport. The viability and contractility of slices were similar to those reported for cultured hypertrophic myocardium [7].

\section{Transcriptome analysis}

To analyze the expression profile for the most highly expressed ORs in human hearts, we used next-generation sequencing data from Flegel et al. (adult heart) and reanalyzed a raw data set from a fetal heart, which was available in the NCBI SRA archive under the GEO accession number GSM1059495 as previously described [28]. The raw sequence data were aligned to the human genome reference sequence (hg19) using TopHat [94]. FPKM (fragments per kilobase of exon per million fragments mapped) values were calculated using the Cufflinks software [95].

\section{RT-PCR}

RNA isolation from heart tissue and stem cell-derived cardiomyocytes and the subsequent RT-PCR were preformed as previously described [60]. The temperature cycle profile was as follows: $5 \mathrm{~min}$ at $95^{\circ} \mathrm{C}$ followed by 35 cycles of $45 \mathrm{~s}$ at $95^{\circ} \mathrm{C}, 45 \mathrm{~s}$ at $60{ }^{\circ} \mathrm{C}, 45 \mathrm{~s}$ at $72{ }^{\circ} \mathrm{C}$ and a final extension of $10 \mathrm{~min}$ at $72{ }^{\circ} \mathrm{C}$. The primers used for RT-PCR were as follows:

NANOG (5'-CAGCCCTGATTCTTCCACCAGTCCC- $3^{\prime}$ and $5^{\prime}$-TGGAAGGTTCCCAGT-CGGGTTCACC-3'), TNN T2 (5'-ATGAGCGGGAGAAGGAGCGGCAGAAC- ${ }^{\prime}$ and

5'-TCAATGGCCAGCACCTTCCTCCTCTC-3'), OR51 E1 (5'-CTCTTCTGGAGGAAGA-CTGG-3' ${ }^{\prime}$ and $5^{\prime}$-GTTA CCTAGCACAGCAATAAGG- $\left.3^{\prime}\right)$, GNAL (5'-CAGACCA GGACCTCCTCAGA- $3^{\prime}$ and $5^{\prime}$-AGGGACTCTCTCAGCC TGTT- $3^{\prime}$ ), ADCY3 (5'-AAGGATTCAACCCTGGGCTC$3^{\prime}$ and $5^{\prime}$-TCCAGCGTCGCATCTCATAG-3'), CNGA2 (5'-TACTCTGGGACCACCACTGA- $3^{\prime}$ and $5^{\prime}$-AACTATC
CTGCGGAAGCCAC-3'), CNGA4 (5'-GAGGTGCTGAG CGAGTATCC- $3^{\prime}$ and $5^{\prime}$-CAGCCGTTCAATGCGGTAA G- $3^{\prime}$ ), CNGB1 (5'-GTCTGAGGCAGCACCTGTAG-3' and $5^{\prime}$-CGTAGAGAAGGTGATCCCGC-3') and intronspanning actin (ACTB) primer to exclude amplification from genomic DNA contamination (5'-GTCTCCCCCTCC ATCGTG- $3^{\prime}$ and $5^{\prime}$-TGGATGCCACAGGATTCCA- $3^{\prime}$ ).

\section{Co-immunoprecipitation and western blot}

The following primary antibodies were used: custom-made affinity purified rabbit polyclonal antibody against OR51E1 (Eurogentec; dilution: 1:250; epitope: LRLFHVATHASEP), polyclonal rabbit anti-G $\alpha_{\mathrm{s} / \text { olf }}$ antibody (Santa Cruz Biotechnology, Dallas, Texas, USA; dilution 1:250) and polyclonal rabbit anti-adenylyl cyclase III antibody (Santa Cruz Biotechnology; dilution 1:250)

Tissue samples were homogenized in lysis buffer (50 mM Tris $\mathrm{HCl}, \mathrm{pH} 7.4,150 \mathrm{mM} \mathrm{NaCl}, 1 \mathrm{mM}$ EDTA, $1 \%$ Triton X-100) with a Complete ${ }^{\circledR}$ protease inhibitor mixture (Roche, Basel, Switzerland) using the Precellys ${ }^{\circledR} 24$ (Bertin Technologies, Montigny-le-Bretonneux, France) and Precellys Ceramic Kit 1.4/1.8 (Peglab, Erlangen, Germany). Samples were centrifuged for $5 \mathrm{~min}$ at $14,000 \mathrm{rpm}$, and the supernatant was isolated and kept on ice. The co-immunoprecipitation experiments were carried out using the Catch \& Release system (Catch \& Release v2.0, Merck Millipore). For this propose the lysate was incubated with primary antibodies (each $2 \mu \mathrm{g}$ ) overnight at $4{ }^{\circ} \mathrm{C}$ in a spin column. After several washing steps, the proteins were eluted from the column using a denaturing elution buffer. Unspecific IgG was used for precipitation as control. Samples were loaded onto a SDS gel and western blot analysis was performed as described by Neuhaus et al. [67], with the slight modification that we used the $\mathrm{ECL}^{\mathrm{TM}}$ Select Western Blotting Detection System (Amersham Biosciences, GE Healthcare, Solingen, Germany) and the Fusion-SL image acquisition system (Vilber Lourmat Deutschland GmbH, Eberhardzell, Germany) for detection.

\section{Immunocytochemistry}

The following primary antibodies were used: custom-made affinity purified rabbit polyclonal antibody against OR51E1 (dilution 1:50), monoclonal mouse anti- $\alpha$-actinin (sacromeric) antibody (Sigma-Aldrich, St. Louis, Missouri, USA; dilution 1:500) and mouse monoclonal anti-rhodopsin antibody 4D2 (Abcam, Cambridge, UK; dilution 1:250).

Stem cell-derived cardiomyocytes or Hana3A cells were seeded on coverslips. Hana3A cells were transfected with rho-tagged OR51E1 plasmid as described in the section titled "Luciferase reporter assay", and the detection of heterologously expressed OR51E1 served to control the 
specificity of the anti-OR51E1 antibody. The cells and human myocardial tissue slices were fixed by incubation with $4 \%$ paraformaldehyde at $4{ }^{\circ} \mathrm{C}$ for $20 \mathrm{~min}$. The specimens were washed and permeabilized in PBS + Triton $\mathrm{X}-100$ (PBST). Blocking was performed in PBST $+1 \%$ gelatin and $5 \%$ goat serum for $1 \mathrm{~h}$ at room temperature. The specimens were then incubated overnight with the primary antibody in PBST $+1 \%$ gelatin at $4{ }^{\circ} \mathrm{C}$. After PBST washing steps, secondary fluorescent IgGs (Life Technologies) (1:1000) and 40,6-diamidino-2-phenylindole (DAPI) were used for visualization. The secondary antibody incubation occurred for $45 \mathrm{~min}$ at room temperature. Afterwards, cells or tissue slices were washed with PBST and covered with Prolong ${ }^{\circledR}$ Gold Antifade reagent (Life Technologies). Micrographs were captured using a LSM510 Meta confocal microscope (Zeiss, Jena, Germany) with a $1024 \times 1024$ or a $2048 \times 2048$ pixel resolution.

Immunizing peptide-blocking experiments were performed to validate antibody specificity; therefore, the antiOR51E1 antibody was preincubated with blocking peptide (Eurogentec, Seraing, Belgium) at a 1:7 ratio for $30 \mathrm{~min}$ at room temperature before proceeding with the staining protocol. Additional proof of the anti-OR51E1 antibody specificity is provided by Maßberg et al. [59]. However, it should be noted that unspecific binding of the antibody, when tested in heart tissue, cannot be completely excluded due to missing knock-down or knock-out controls.

\section{siRNA transfection}

Stem cell-derived cardiomyocytes were transiently transfected with either targeted or negative control siRNAs (OR51E1 Silencer ${ }^{\circledR}$ Pre-designed siRNA s44550 and Silencer ${ }^{\circledR}$ Select Negative Control No. 1 siRNA; Life Technologies) using Lipofectamine ${ }^{\circledR}$ RNAiMAX (Life Technologies) according to the manufacturers' instructions. The transfection rates were less than $1 \%$ with both OR51E1 siRNA and control siRNA as detected by co-expression of GFP.

\section{Luciferase reporter assay}

The Dual-Glo Luciferase Assay System (Promega, Madison, Wisconsin, USA) is the most commonly used method for high-throughput screening of odorant receptor pairs $[14,56,75,86,113]$. This method quantifies cellular responses as an indirect measure of odorant receptor activation as previously described [117]. Hana3A cells seeded on a 96-well plate (Thermo Fisher Scientific, Waltham, Massachusetts, USA) were transfected at $60-70 \%$ confluence with Lipofectamine 2000 (Life Technologies) using $18 \mu \mathrm{l}$ Lipofectamine, $1 \mu \mathrm{g}$ of RTP1S plasmid [116], $1 \mu \mathrm{g}$ of pRL-TK-Renilla (Promega), $2 \mu \mathrm{g}$ of pGL4.29-luciferase (Promega), $1 \mu \mathrm{g}$ of hM3 [51] and $5 \mu \mathrm{g}$ of full-length rho4D2-tagged OR51E1 in pCI (Addgene Cambridge, Massachusetts, USA) for an entire well plate. Approximately $18-24 \mathrm{~h}$ after transfection, the transfection medium was removed and replaced with the appropriate concentration of odorant, diluted in DMSO, $0.1 \%$ DMSO (negative control) or $10 \mu \mathrm{M}$ forskolin (positive control) in CD293 (Life Technologies) with $2 \mathrm{mM}$ L-glutamine. Most of the odorants were provided as a generous gift from Dr. J. Panten (Symrise, Holzminden, Germany; Table S1). Four hours after odor stimulation, luminescence was measured using a Fusion microplate reader (Packard BioScience PackardBioScience, Meriden, Connecticut, USA). Firefly luminescence values were divided by the Renilla luciferase activity as a control for transfection efficiency in a given well. The firefly-Renilla luciferase ratio was normalized against the lowest/highest luciferase ratios obtained for that experiment. Normalized luciferase activity was calculated by the formula [Luc/ $\operatorname{Ren}(\mathrm{N})$ - Luc/Ren(lowest)]/[Luc/Ren(highest) - Luc/

Ren(lowest)], where Luc/Ren(N) is the luminescence of firefly luciferase divided by the luminescence of Renilla luciferase in a certain well; Luc/Renilla(lowest) is the lowest luciferase ratio of OR51E1 transfected cells to negative control; Luc/Ren(highest) is the maximum luciferase ratio of OR51E1 transfected cells to forskolin or nonanoic acid $(1000 \mu \mathrm{M})$ of a plate. Mock-transfected cells were stimulated to exclude unspecific responses to the tested compounds. Data were analyzed using Microsoft Excel ${ }^{\circledR}$ (Microsoft, WA, USA) and SigmaPlot (Systat Software Inc., San Jose, CA, USA).

\section{$\mathrm{Ca}^{2+}$ imaging}

Stem cell-derived cardiomyocytes plated on glass were incubated for $25 \mathrm{~min}$ in loading buffer ( $\mathrm{pH}$ 7.4) containing Ringer's solution $(140 \mathrm{mM} \mathrm{NaCl}, 5.9 \mathrm{mM} \mathrm{KCl}, 10 \mathrm{mM}$ HEPES, $2 \mathrm{mM} \mathrm{CaCl} 2,1 \mathrm{mM} \mathrm{MgCl} 2,10 \mathrm{mM}$ glucose and $2 \mathrm{mM}$ Na-pyruvate) and 7.5 $\mu \mathrm{M}$ Fura-2-AM (Life Technologies, Carlsbad, CA, USA). After removal of extracellular Fura-2 by washing with Ringer's solution, ratiofluorometric $\mathrm{Ca}^{2+}$ imaging was performed using a Zeiss inverted microscope equipped for ratiometric imaging and a Polychrome V monochromator (TILL Photonics, Graefelfing, Germany). Images were acquired at $10 \mathrm{~Hz}$, and integrated fluorescence ratios $\left(f_{340} / f_{380}\right)$ were measured using TILLvisION software (TILL Photonics). Cells were visualized with a $20 \times$ objective (UPLSAPO, Olympus, Tokio, Japan). Images were acquired in randomly selected fields of view. Carbachol and inhibitors were purchased from Sigma-Aldrich or Tocris (R\&D Systems, Minneapolis, MN, USA). Odorants were prediluted in DMSO 
(Sigma-Aldrich) and then diluted in Ringer's solution such that the DMSO concentration did not exceed $0.1 \%(\mathrm{v} / \mathrm{v})$, which was well tolerated by cardiomyocytes. The data for Fura-2 calcium transients were analyzed with a self-written script in Spike ${ }^{\circledR}$ analysis software (Cambridge Electronic Design, Cambridge, UK) and partly by Chart5 ${ }^{\circledR}$ (ADInstruments, Oxford, UK, http://www.adinstruments.com). Basic statistical analysis was performed in Excel ${ }^{\circledR}$ and Sigmaplot.

\section{Contractile force measurements of slice preparations of adult human ventricle}

Myocardial slices with a surface area of approximately $5 \times 5 \mathrm{~mm}^{2}$ were mounted onto a horizontal organ bath (Mayflower, Hugo Sachs Elektronik, March, Germany) and were superfused with gassed Ringer solution $\left(5 \% \mathrm{CO}_{2}, 20 \%\right.$ $\mathrm{O}_{2}, 37^{\circ} \mathrm{C}$ ) at $4 \mathrm{ml} / \mathrm{min}$ as previously described [7]. The isometric contraction force was measured at a preload of $1.5 \mathrm{mN}$ under continuous field stimulation (rate $0.5 / \mathrm{s}$, pulse duration $3 \mathrm{~ms}$ ) at a 1.5-fold excitation threshold. The relative alteration of the twitch force before and after drug application was evaluated. For drug application, perfusion of the organ bath was stopped and fatty acids dissolved in DMSO were added at $0.1 \% \mathrm{v} / \mathrm{v}$ to the organ bath. Increasing concentrations of the same fatty acid were tested in sequential applications, which were separated by 4-min intervals of perfusion and equilibration. Preparations that developed a twitch force of less than $0.4 \mathrm{mN}$ or reacted by more than a $5 \%$ change in contractility to $0.1 \%$ DMSO were discarded. Substances that caused a change of less than $5 \%$ in the twitch force at their maximum concentration $(1 \mathrm{mM})$ were considered inactive. Because of the transient action of some of the fatty acids, the acids' effects on the twitch force were analyzed as minimum and final values over a 4-min period of exposure.

\section{Contractile force measurements of trabeculae carneae}

Within $2 \mathrm{~h}$ after explantation, trabeculae carneae of the left ventricle were prepared and fixed in a horizontal organ bath setup. Contractions of the muscle were induced by an STI08 stimulator at a rate of $1 \mathrm{~Hz}$. Diastole and systole were detected via mechanical transducers and an FMI TMI1020-Shor amplifier. Signals were recorded with BEMON FMI VitroDat 3.4 software (Föhr Medical Instruments GmbH, Seeheim, Germany). Trabeculae carneae were submerged in warm $\left(37^{\circ} \mathrm{C}\right)$ and oxygenated physiological buffer solution with a precisely controlled $\mathrm{pH}$ of 7.4. Prior to the beginning of each experiment, the contraction force of the trabeculae carneae was maximized by raising the tension to achieve an optimal preload (Frank-Starling mechanism). Because overstretching leads to damage of the contractile elements and a subsequent loss of contraction force, the tension was raised in small, carefully controlled steps. After optimizing the applied tension, the application of substances was delayed until a steady contraction force was observed. Substances were directly added to the bath solution. At the beginning of the measurements, $5 \times 10^{-8} \mathrm{M}$ isoprenaline (Sigma-Aldrich), a beta-receptor agonist, was applied to the organ bath to further elevate the contraction force of the muscle. Following this prestimulation, increasing concentrations of the OR51E1 ligand, nonanoic acid, were applied to the bath solution. The administered concentration started at $1 \mu \mathrm{M}$, with the concentration increased fivefold every 5-10 min until $5 \mathrm{mM}$ was reached. Meanwhile, changes in the contraction force were closely monitored. To exclude possible toxic effects of nonanoic acid, stimulation with $1 \mathrm{mM}$ isoprenaline was performed after each experiment.

\section{Determination of the fatty acid pattern in the triglyceride and non-esterified fatty acid fraction from epicardial adipose biopsies and from plasma}

Approximately $25 \mathrm{mg}$ of human epicardial adipose tissue was homogenized using a TissueLyser MM 300 (Qiagen, Hilden, Germany) in $0.25 \mathrm{ml} 1 \%$ Triton X-100 in PBS. Then, $1.25 \mathrm{ml}$ 2-propanol, $n$-heptane and $2 \mathrm{~mol} / \mathrm{l}$ phosphoric acid (40:20:1 by vol) were added to the tissue extract or to $0.25 \mathrm{ml}$ plasma samples and mixed by vortexing. After $10 \mathrm{~min}, 0.5 \mathrm{ml}$ toluene/methanol (4:1 by vol) and $0.75 \mathrm{ml}$ water were added and mixed by vortexing, and after centrifugation at $4000 \mathrm{rpm}$ $(8175 \mathrm{~g})$, the upper phase was dried under stream of nitrogen. The lipids were dissolved in $75 \mu \mathrm{CHCl}_{3} / \mathrm{CH}_{3} \mathrm{OH}$ (2:1 by vol) and applied to a silica gel chromatography plate (Merck, Darmstadt, Germany). The lipid fractions were separated using a mixture of $n$-hexane, diethylether and acetic acid (160:40:6 by vol) as a solvent. The lipid fractions were identified using a pooled control plasma and were separated on each plate; the lipid fractions were then visualized by 2,7dichlor-fluoresceine under ultraviolet light. The fractions were scraped off the TLC plate, transferred to screw-capped vials and dissolved in a $2 \mathrm{ml}$ methanol/toluene mixture (1:4 by vol) containing cis-13,16,19-docosatrienoic acid $(10 \mu \mathrm{g} / \mathrm{ml})$ as an internal standard. Trans-esterification was performed by incubation with acetyl chloride at $100{ }^{\circ} \mathrm{C}$ for $60 \mathrm{~min}$. The cold sample was neutralized with $5 \mathrm{ml} 6 \% \mathrm{~K}_{2} \mathrm{CO}_{3}$, shaken for $2 \mathrm{~min}$, and centrifuged, and the upper phase was concentrated to $100 \mu \mathrm{l}$ under nitrogen. The fatty acid methyl esters were measured by gas chromatography $7890 \mathrm{~A}$ with a flame ionization detector (Agilent, Waldbronn, Germany) and quantified using the corresponding fatty acids standards. All data analysis were performed using the JMP 11.0 software package (SAS Institute, Cary, NC, USA). 


\section{Results}

\section{Olfactory receptor OR51E1 is expressed in the human heart and in stem cell-derived cardiomyocytes}

Comparative transcriptome analysis of OR expression identified OR51E1 in various human tissues, including the heart $[28,32]$. In the human adult and fetal heart, OR51E1 is the highest expressed OR (adult 1.50 FPKM; fetal 1.35 FPKM), with an expression level similar to that of the beta-
2 adrenergic receptor and the muscarinic acetylcholine receptor M2 (Fig. 1a). On a rough scale, 1 FPKM corresponds to a weak expression level, 10 FPKM represents a moderate expression level and 100 FPKM indicates a high expression level. Moreover, OR51E1 is one of the few ORs for which the ligand (nonanoic acid) has been identified $[1,80]$. Therefore, in this study, we focused on OR51E1 for functional characterization of ORs in the human heart. First, we validated the results of the transcriptome analysis using reverse transcription PCR (RTPCR) and could detect transcripts of OR51E1 in the
A

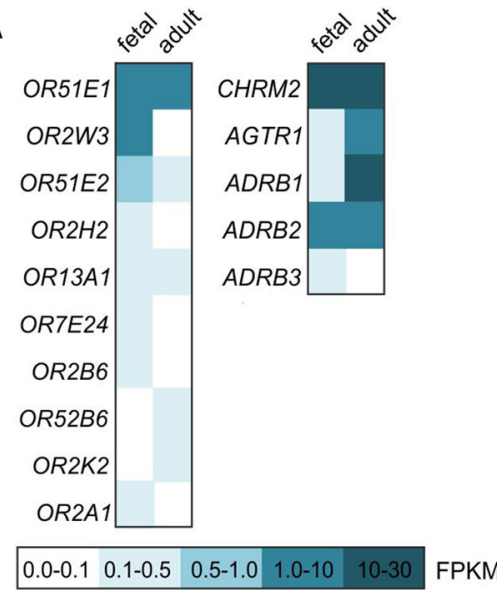

C

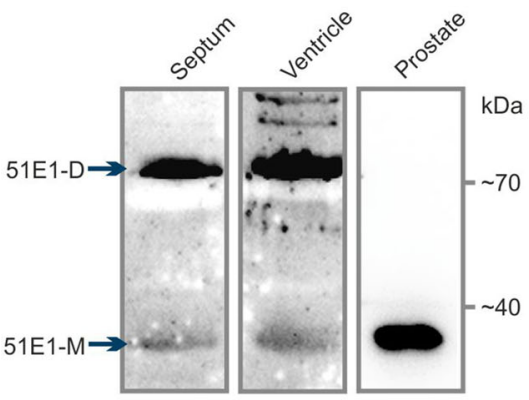

B

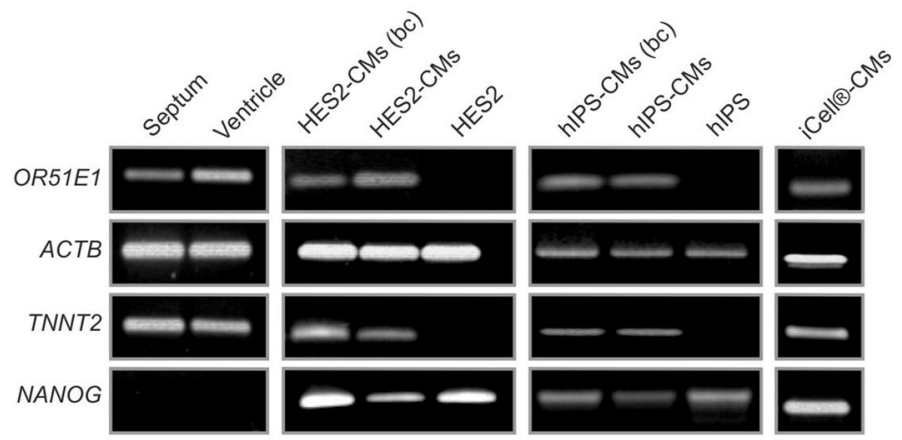

D

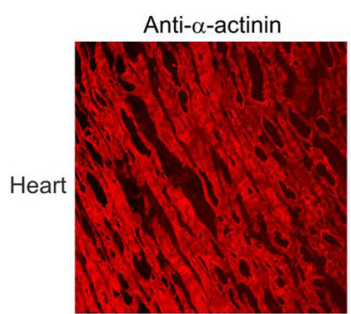

Anti-OR51E1

merge
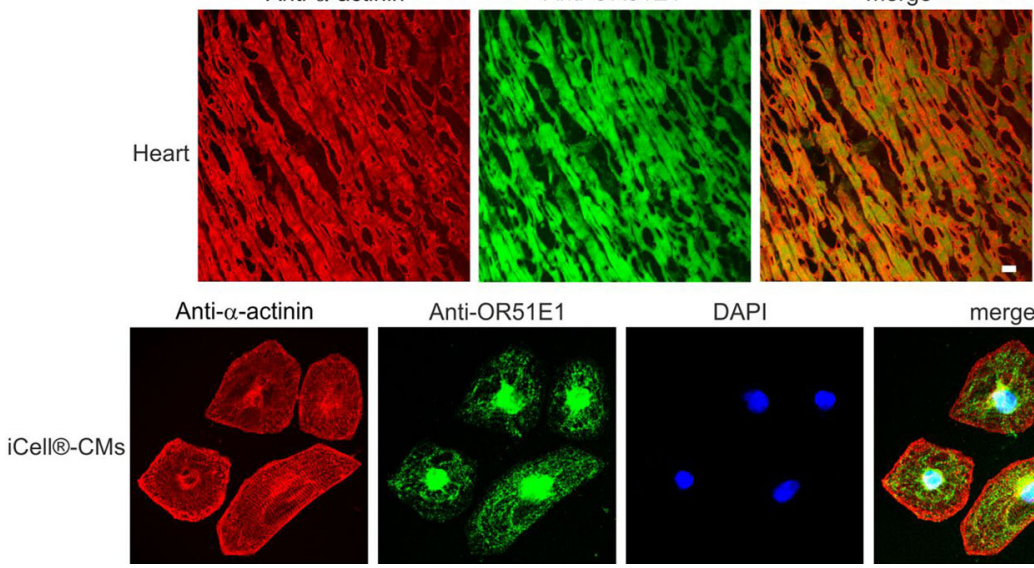

Anti-OR51E1

DAPI

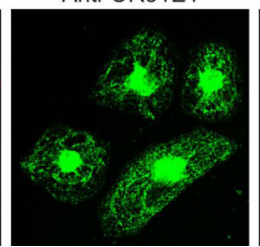

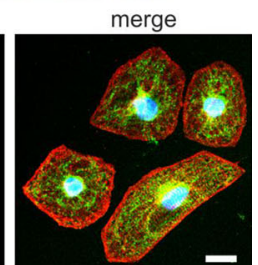

Fig. 1 Expression of OR51E1 in the human heart tissue and stem cell-derived cardiomyocytes. a Expression pattern of ORs as revealed by next-generation sequencing analysis. The heat map shows FPKM values for ORs and classical cardiac GPCRs (CHRM2, muscarinic acetylcholine receptor $\mathrm{M}_{2}$; AGTR1, angiotensin II receptor type 1; ADRB1, beta-1 adrenoceptor; ADRB2, beta-2 adrenoreceptor; ADRB3, beta-3 adrenoreceptor) found in human adult and fetal heart tissue analyzed. Dark aquamarine indicates high expression (FPKM values higher than 10), and white indicates the absence of detectable transcripts. b Detection of OR51E1 transcripts in the left ventricle and septum of explanted human heart and in stem cellderived cardiomyocytes by RT-PCR. Amplification of $\beta$-actin (ACTB) using intron-spanning primers served to control cDNA quality. Cardiac muscle troponin $\mathrm{T}$ (TNNT2) expression identifies induced cardiomyocytes (CMs) and nanog homeobox (NANOG) expression undifferentiated stem cells. HES2-CMs: human embryonic stem cellderived cadiomyocytes, hIPS-CMs: human induced pluripotent stem cell-derived cardiomyocytes, (bc) indicates beating cell clusters in stem cell-derived cardiomyocytes that were excised for RNA preparation under optical control. OR51E1 is expressed in cardial myocytes of embryonic and adult stem cell origin, not in undifferentiated stem cells. c Detection of OR51E1 protein in the left ventricle and septum of explanted human heart and prostate as control by western blotting, the size of the OR51E1 monomeric (51E1-M) protein is $35 \mathrm{kDa}$ and dimeric (51E1-D) $70 \mathrm{kDa}$. d Detection of OR51E1 protein in ventricular myocytes and stem cell-derived cardiomyocytes by immunohistochemical staining. Shown are confocal micrographs of OR51E1 immunostaining obtained using an OR51E1-specific antibody in transversal cryosections of human left ventricle. Cardiomyocytes were identified by co-staining with an $\alpha$ actinin-detecting antibody. The lower panel shows immunostaining of stem cell-derived cardiomyocytes with anti- $\alpha$-actinin and antiOR51E1 antibodies. Cell nuclei were stained with $4^{\prime}, 6$-diamidino-2phenylindole (DAPI). Bar indicates $20 \mu \mathrm{m}$ 
investigated septum and ventricle of the human heart (Fig. 1b). For the detection of OR51E1 receptor proteins, we performed western blotting and immunohistochemical analysis using a custom-made OR51E1 antibody. The antibody specificity was demonstrated by co-immunocytochemical staining of Hana3A cells heterologously expressing rho-tagged OR51E1 (see supplementary Figure S1A) and by using of a specific OR51E1-blocking peptide (Figure S2). Western blot analysis revealed OR51E1 protein expression in the human septum and ventricle. Prostate cancer tissue served as a positive control for the detection of OR51E1 protein [101, 105] (Fig. 1c). Immunohistochemical analysis of human ventricular tissue sections further confirmed our results regarding myocardial OR51E1 protein expression. To study receptor activation, we used an established cardiac in vitro model, hIPSCs and hESC-derived cardiomyocytes that are spontaneously electrically active [92]. The expression of OR51E1 mRNA in different stem cell-derived cardiomyocytes was confirmed by RT-PCR and the subcellular localization of OR51E1 was elucidated by immunocytochemical staining (Fig. 1b, d).

\section{Ligand screening on OR51E1}

Previous de-orphanization studies have identified inter alia nonanoic acid as an activating ligand for OR51E1 [1, 80] (Figure S3A, B, D). To characterize the molecular receptive field of OR51E1 in greater detail, we conducted luciferase reporter assays using Hana3A cells heterologously expressing OR51E1 and based on the known ligand nonanoic acid we test further 36 structurally related odorant on their ability to activate the receptor (Table S1). We identified 13 new agonists by testing at an odorant concentration of $500 \mu \mathrm{M}$ (except poorly soluble substance) to ensure receptor activation above the detection threshold (Fig. 2a; Figure S3). Moreover, we identified an antagonist for OR51E1. OR51E1-activating substances are short- to middle-chain (C4-C14) saturated or monounsaturated acids (Fig. 2a), some of which are dietary fats. Among the tested compounds, decanoic acid (C10:0) appears to be the most efficient agonist (Figure S3C; EC $_{50} 190 \mu \mathrm{M}$ ), whereas an increasing or decreasing chain length and insertion of branches or additional double bonds into the compound resulted in a reduced potency to activate the receptor (Fig. 2a; Figure S3). Furthermore, our results indicate that the presence of one free terminal carboxyl group is crucial for receptor recognition because substitution by aldehyde, ester, amide or alcohol groups abolished activation of the heterologously expressed receptor. In a screen for inhibitors, we identified 2-ethylhexanoic acid as an antagonist of OR51E1, which significantly reduced the nonanoic acid-induced luminescent signal. The half maximal inhibitory concentration $\left(\mathrm{IC}_{50}\right)$ of 2-ethylhexanoic acid was calculated with $179 \mu \mathrm{M}$ (using a concentration of $200 \mu \mathrm{M}$ nonanoic acid) (Fig. 2b). We observed a significant shift in the dose-response curve for nonanoic acid with and without the antagonist. The $\mathrm{EC}_{50}$ value shifted significantly from $215 \mu \mathrm{M}( \pm 16)$ to $375 \mu \mathrm{M}( \pm 41)$ $(p=0.011)$. The OR51E1 activity induced by the saturating nonanoic acid concentration of $2 \mathrm{mM}$ was not significantly reduced in the presence of 2-ethylhexanoic acid (400 $\mu \mathrm{M})$, which indicates, together with the parallel shift in the dose-response curve, a competitive antagonistic mechanism (Fig. 2c).

\section{OR51E1 activation induces a negative chronotropic effect in human stem cell-derived cardiomyocytes}

We next investigated the physiological function of OR51E1 activating ligand nonanoic acid [1, 80] on calcium handling in stem cell-derived cardiomyocytes via the $\mathrm{Ca}^{2+}$ imaging method. Interestingly, short-term application (1 min) of nonanoic acid inhibited spontaneous $\mathrm{Ca}^{2+}$ transients in a dose-dependent manner. The muscarinic acetylcholine receptor agonist carbachol served as a positive control for a negative chronotropic effect [39, 106] (Fig. 3a). Detailed statistical analysis of the intracellular $\mathrm{Ca}^{2+}$ dynamics of stem cell-derived cardiomyocytes revealed that nonanoic acid significantly reduced the frequency of $\mathrm{Ca}^{2+}$ spikes and increased the time to peak, decay 50 and peak duration, whereas other parameters (baseline, amplitude, $v_{\max }$ peak and $v_{\min }$ peak) remained unaffected (Fig. 3b). Dose-response curves showed that nonanoic acid reduced the frequency of $\mathrm{Ca}^{2+}$ spikes down to $60 \%$ compared with the basal frequency in all three tested stem cell-derived cardiomyocyte types $\left(\mathrm{EC}_{50}\right.$ $151 \pm 12 \mu \mathrm{M}$ ) (Fig. 3c). We next analyzed the effect of other OR51E1 agonists on iCell ${ }^{\circledR}$ cardiomyocytes. We tested decanoic, dodecanoic and tetradecanoic acid in $\mathrm{Ca}^{2+}$ imaging experiments and observed that all three fatty acids induced a negative chronotropic effect in human stem cellderived cardiomyocytes in a dose-dependent manner (Fig. 3d). Dodecanoic and tetradecanoic acid could only be used at low concentrations because higher concentrations were incompletely soluble. Notably, diluted OR51E1 ligands did not affect the neutral $\mathrm{pH}$ of the applied solutions at the tested concentrations, and the solvent (DMSO) did not exhibit any effect when applied alone (Figure S4A). Compounds that were inactive on the heterologously expressed OR51E1, such as propionic or cinnamic acid, did not affect the $\mathrm{Ca}^{2+}$ spike frequency of stem cell-derived cardiomyocytes (Figure S4B). Thus, the receptive field of heterologously expressed OR51E1 was in accord with the ligand profile observed in stem cell-derived cardiomyocytes. 


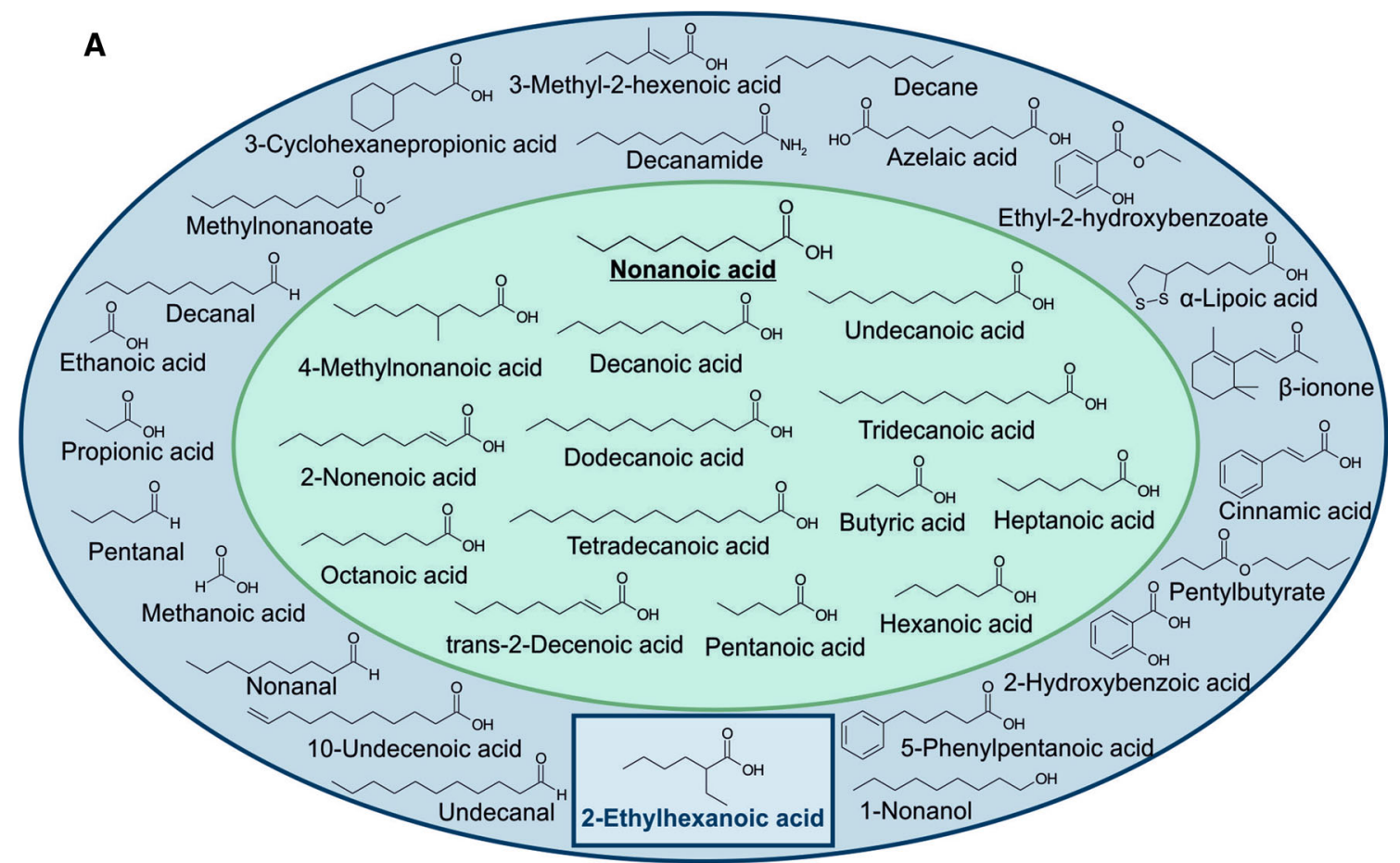

B

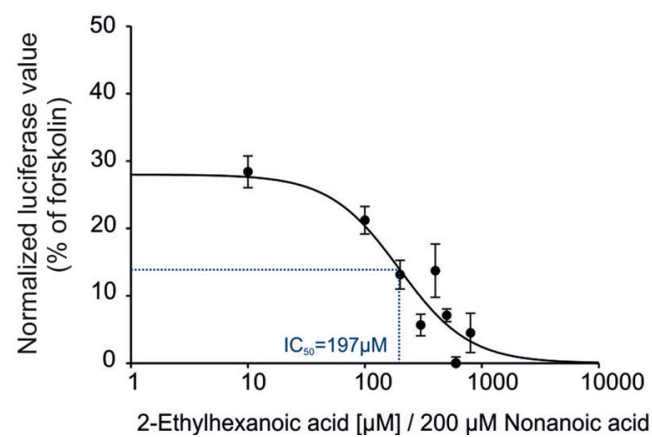

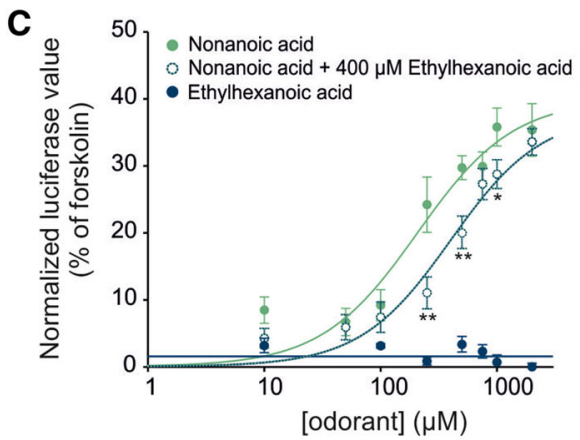

Fig. 2 Ligand spectrum of OR51E1. a Molecular receptive field of OR51E1. Structurally related molecules were tested in luciferase reporter assays for their ability to activate heterologously expressed OR51E1, using nonanoic acid as a template. Effective ligands are shown in a green field; inactive compounds are in a blue field. Receptor-inhibiting substance is shown in a blue rectangle. The active analog approach identifies a mono carboxyl functional group as key feature for OR51E1 activation; alkyl side chain length can vary from $\mathrm{C} 4$ to $\mathrm{C} 14$; methyl substitutions are not tolerated at $\mathrm{C} \beta$. Double bonds are tolerated at $\mathrm{C} \beta$ but affect negatively the activating property of the compound at $\mathrm{C \kappa}$ (e.g., undecanoic acid: activating, 10-undecenoic acid: inactive). Aromatic functional groups are not tolerated. b Concentration-inhibition curve. Each response was normalized to the

We confirmed by antagonist and receptor knock-down experiments that the observed effect of nonanoic acid primarily depends on OR51E1. For this purpose, we used RNAi to silence endogenously expressed OR51E1 in stem cell-derived cardiomyocytes. First, we investigated the knock-down efficiency via immunocytochemical staining. Cardiomyocytes were transfected with small interfering agonist nonanoic acid $(200 \mu \mathrm{M})$ alone. The calculated $\mathrm{IC}_{50}$ was $192 \mu \mathrm{M}$. The curve shift was significant at concentrations higher than $100 \mu \mathrm{M}$ 2-ethylhexanoic acid $(* p<0.05)$. c Dose-response curves in the presence of OR51E1 antagonist. To determine receptor-inhibiting properties of compounds, OR51E1-expressing cells were co-stimulated with a rising concentration of nonanoic acid and a fixed concentration of 2-ethylhexanoic acid $(400 \mu \mathrm{M})$. The mean of cellular responses was measured by luciferase reporter assays in four biological replicates and normalized to the positive control (forskolin). 2-ethylhexanoic acid acts as a competitive inhibitor on OR51E1. Significance was calculated by Student's $t$ test $(* p<0.05$, $* * p<0.01$ and $* * * p<0.001)$. Error bars represent the SEM

siRNA or scrambled scRNA as a negative control and a GFP-plasmid as a transfection control. Immunocytochemical analysis verified a reduction in the receptor expression level in vitro (Fig. 4a). Subsequently, we performed $\mathrm{Ca}^{2+}$ imaging experiments on RNAi expressing cardiomyocytes. The nonanoic acid-induced reduction of the $\mathrm{Ca}^{2+}$ spike frequency effect was quantified, whereby the results of 


\section{A}

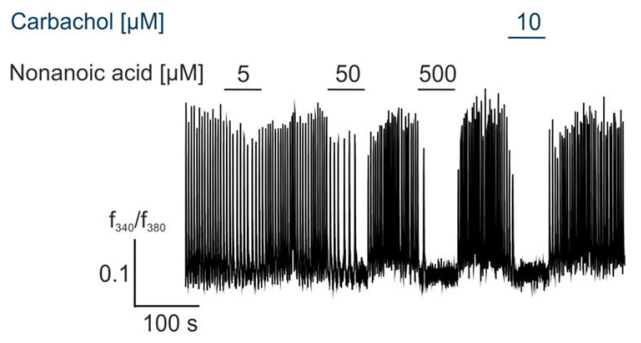

C

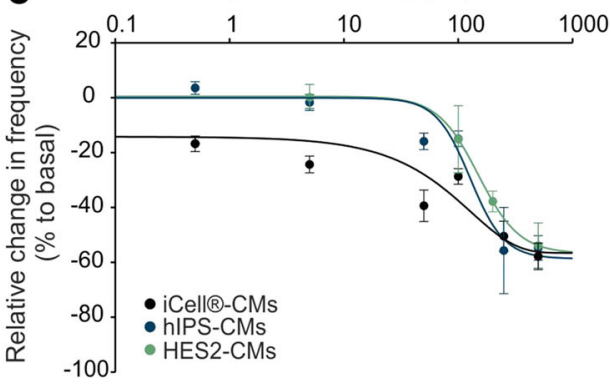

Fig. 3 OR51E1-activation induces negative chronotropic effects in stem cell-derived cardiomyocytes. a Representative $\mathrm{Ca}^{2+}$ imaging trace of a Fura-2-loaded human-induced pluripotent stem cell-derived cardiomyocyte (hIPS-CM). Cytosolic $\mathrm{Ca}^{2+}$ levels were monitored as the integrated $f_{340} / f_{380}$ fluorescence ratio expressed as a function of time. Horizontal bars indicate time and duration of stimulus application. In a randomly selected field of view, application of nonanoic acid inhibited spontaneous $\mathrm{Ca}^{2+}$ transients in a dosedependent manner. Carbachol $(10 \mu \mathrm{M})$ served as positive control for negative chronotropy. b Statistical analysis of the effect of nonanoic acid $(500 \mu \mathrm{M})$ on intracellular $\mathrm{Ca}^{2+}$ dynamics of cardiomyocytes. Relevant parameters of the $\mathrm{Ca}^{2+}$ transients during stimulus application were quantified by Spike2 and normalized to the basal value. Analysis of the resulting $\mathrm{Ca}^{2+}$ transients revealed that the frequency,

siRNA- and scRNA-expressing cells were compared with those of non-transfected control cells within the same experiment. The OR51E1-specific siRNA knockdown resulted in a significant reduction of the nonanoic acidinduced negative chronotropic effect, whereas the carbachol response remained unaffected (Fig. 4b). To provide further evidence for the receptor dependence of the observed nonanoic acid-induced effect, we performed OR51E1 antagonist experiments. Co-application of antagonist 2-ethylhexanoic acid reversed nonanoic acid-induced negative chronotropy, whereas the application of the antagonist alone did not affect the $\mathrm{Ca}^{2+}$ spike frequency of stem cell-derived cardiomyocytes (Fig. 4c). We, therefore, concluded that the observed negative chronotropic effect results from OR51E1 activation.
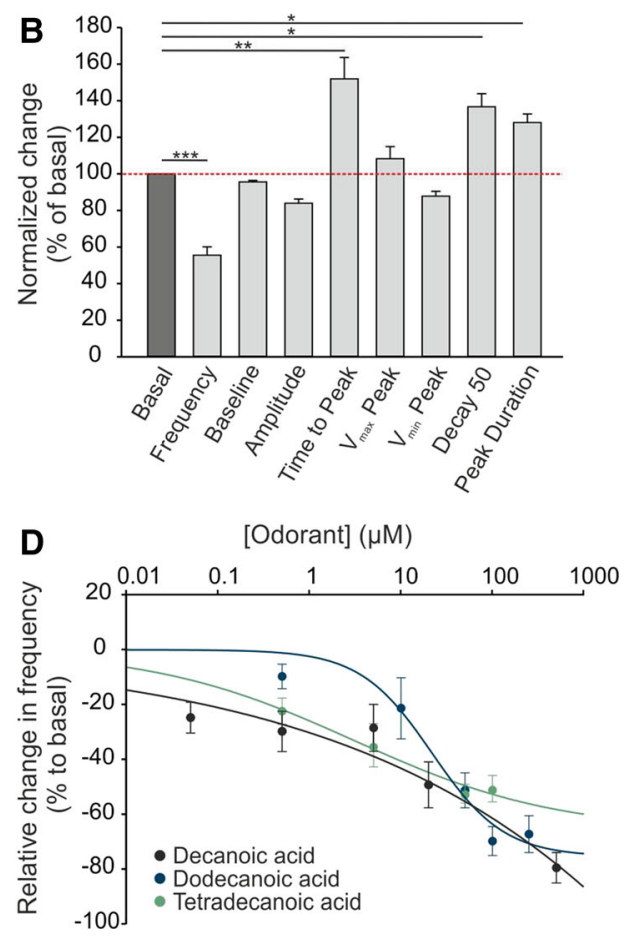

time to peak, decay 50 and peak duration were significantly altered during nonanoic acid stimulation. The mean baseline, amplitude, $v_{\max }$ peak and $v_{\text {min }}$ peak remain unchanged. Means were averaged from 25 to 37 experiments. Error bars represent the SEM. Significance was calculated by Student's $t$ test or Mann-Whitney $U$ test $(* p<0.05$, $* * p<0.01$ and $* * * p<0.001)$. c Nonanoic acid-induced negative chronotropy is cell type-independent. $\mathrm{Ca}^{2+}$ spike frequency of iCell ${ }^{\circledR}$-CMs, hIPS-CMs and HES2-CMs decreases in a dose-dependent manner up to approximately $60 \%$. The graph shows the percentage change in the frequency from the basal value. Means were averaged from 5 to 37 experiments. d Negative chronotropic effect of iCell ${ }^{\circledR}$-CMs to OR51E1 ligands: decanoic, dodecanoic and tetradecanoic acid. The data are shown as the mean $\pm \operatorname{SEM}(n>29)$

\section{OR51E1 signaling involves G protein activation}

We next investigated the OR51E1-induced signaling mechanism in cardiomyocytes. In olfactory sensory neurons, the OR-activated signal transduction cascade involves the $\mathrm{G} \alpha_{\text {olf }}$ subunit, adenylyl cyclase III (AC-III) and the cyclicnucleotide gated (CNG) channel (subunits CNGA2, CNGA4 and CNGB1) [62], whereas in ectopic tissues OR signaling can occur independently of G proteins [89]. RT-PCR results revealed that the $\mathrm{G} \alpha_{\text {olf }}(G N A L)$ is expressed only in the human septum and AC-III (ADCY3) in the human ventricle, whereas olfactory CNG channel subunits were not detected at all (Fig. 5a). Protein expression of both $\mathrm{G} \alpha_{\mathrm{s} / \mathrm{olf}}$ and AC-III was confirmed by western blotting in human heart tissue (Fig. 5b). In stem cell-derived cardiomyocytes, which 

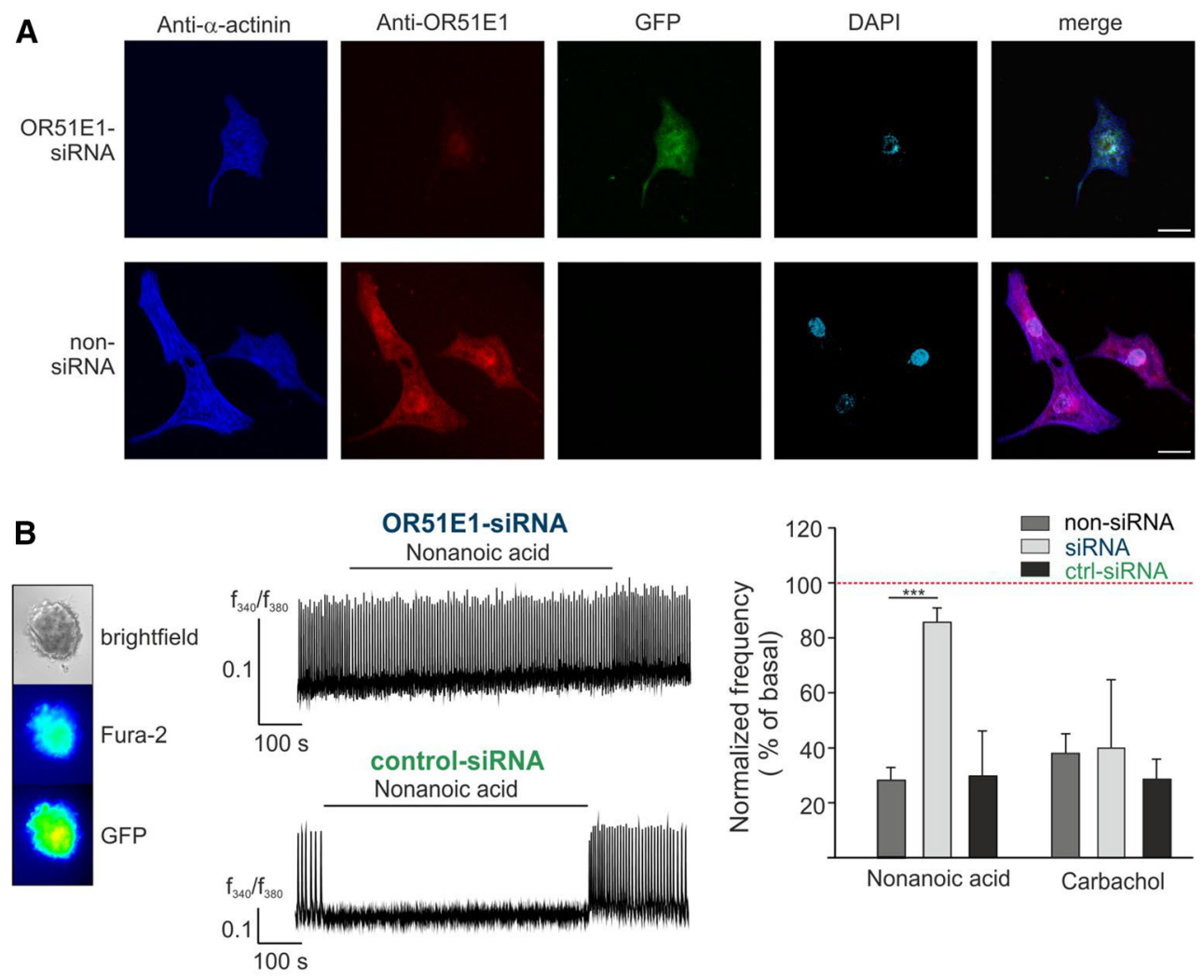

C
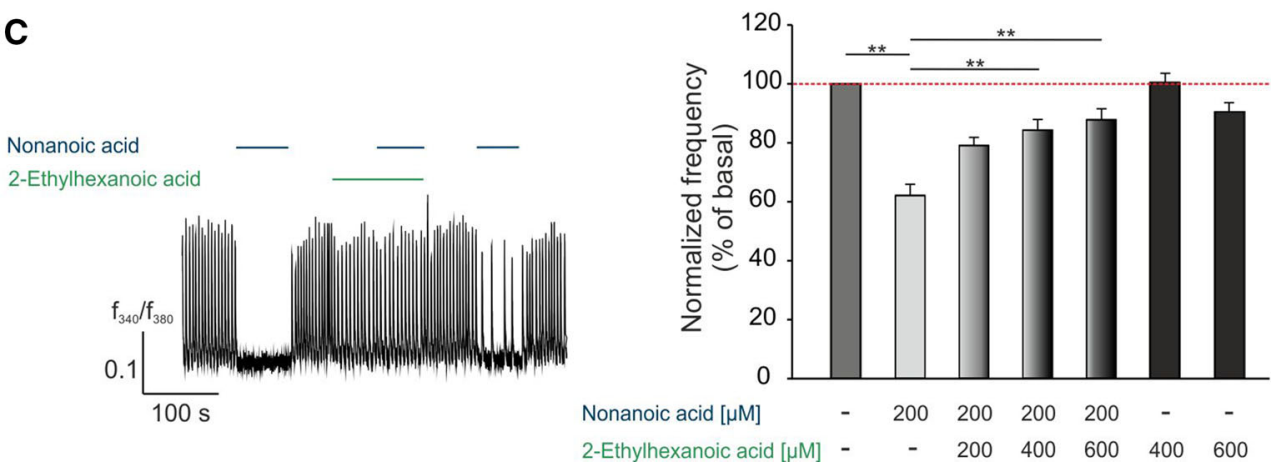

Fig. 4 OR51E1 dependent induction of a negative chronotropic effects in stem cell-derived CMs by nonanoic acid. a Knock-down of OR51E1 was verified by immunostaining. HES2-CMs were transfected with siRNA directed against OR51E1. Because siRNA was cotransfected with a plasmid encoding for GFP, siRNA-expressing cells could be identified via GFP fluorescence. Immunostaining of HES2CMs with anti- $\alpha$-actinin (blue), anti-OR51E1 (red) antibodies and DAPI (4',6-diamidino-2-phenylindole) staining (turquoise) was used to determine the number and location of cells. Control staining was performed without siRNA transfection (lower panel). Bar indicates $20 \mu \mathrm{m}$. b Ca ${ }^{2+}$ imaging experiments with siRNA-transfected HES2CMs. Because the siRNA- or scRNA-constructs were co-transfected with GFP-plasmid, siRNA/sc-RNA-expressing cells could be detected via GFP fluorescence (left panel). The middle panel shows representative $\mathrm{Ca}^{2+}$ traces of siRNA-transfected cardiomyocytes. Nonanoic acid-induced negative chronotropy was abolished in OR51E1-siRNA expressing hIPS-CMs (right panel, blue) compared with scrambled
OR51E1-siRNA (ctrl-siRNA) expressing cells (right panel, green). Carbachol $(10 \mu \mathrm{M})$ served as a positive stimulus to control cell viability. Bars represent the means of 12 independent transfection experiments, and error bars represent the SEM. Significance was calculated by Student's $t$ test $(* * * p<0.001)$. Negative chronotropy induced by OR51E1 agonist resulted from OR51E1 activation. c Coapplication of the OR51E1 antagonist 2-ethylhexanoic acid prevents nonanoic acid-induced negative chronotropic effect in a $\mathrm{Ca}^{2+}$ imaging measurement of HES2-CMs. The blocking effect was reversible because nonanoic acid-induced negative chronotropy was restored after washout of the antagonist (left panel). Quantification of $\mathrm{Ca}^{2+}$ spike frequency of co-stimulated $\mathrm{CMs}$ with a constant concentration of nonanoic acid and a rising concentration of the antagonist in $\mathrm{Ca}^{2+}$ imaging experiments (right panel). The data are shown as the mean $\pm \operatorname{SEM}(n=14-30)$. Significance was calculated by Student's $t$ test $(* * p<0.01)$ 


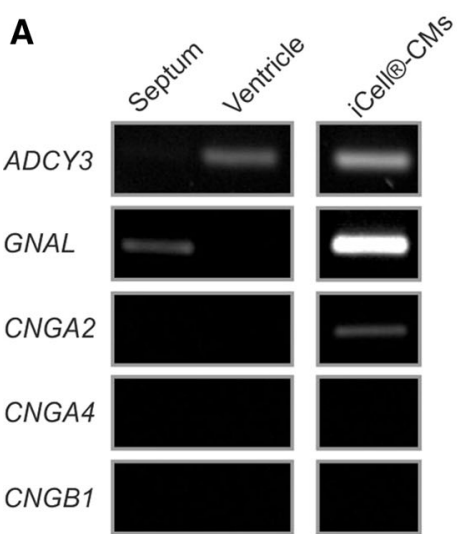

B
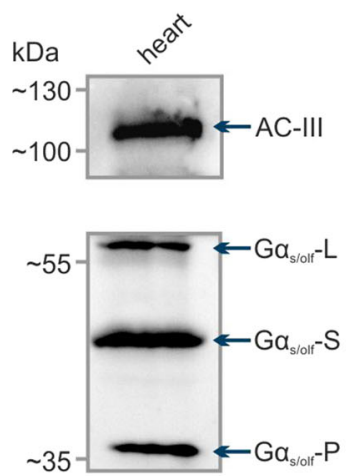

C

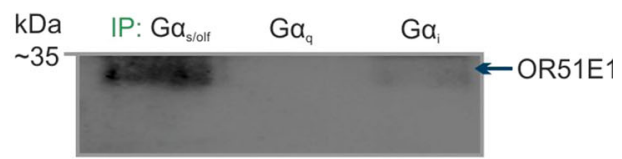

D

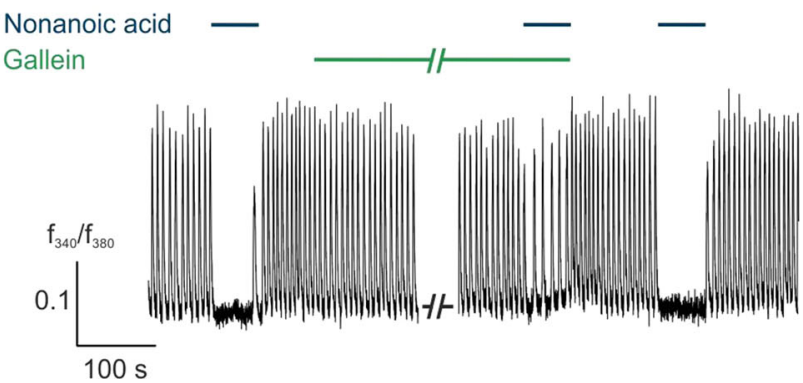

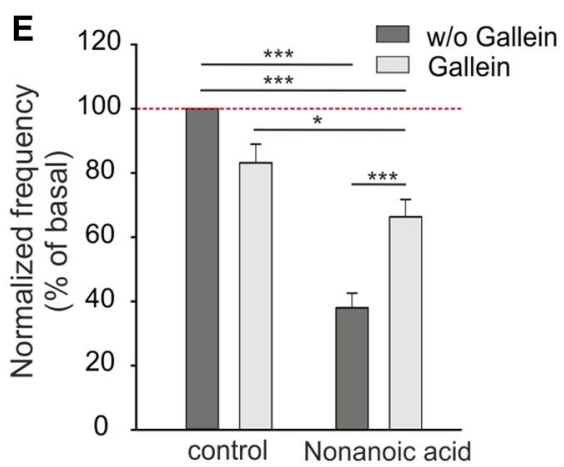

Fig. 5 OR51E1 signaling in CMs. a Detection of transcripts of ORsignaling pathway components, including $\mathrm{G} \alpha_{\text {olf }}(G N A L)$, adenylyl cyclase III (ADCY3) and CNG channel subunits (CNGA2, CNGA4 and $C N G B 1$ ) in ventricle and septum of explanted human heart and iCell ${ }^{\circledR}-\mathrm{CMs}$ by RT-PCR. b Verification of $\mathrm{G} \alpha_{\text {olf }}$ protein and AC-III expression in human heart tissue by western blot. The molecular size of the two splice variants of $\mathrm{G} \alpha_{\mathrm{s} / \mathrm{olf}}$ are $45 \mathrm{kDa}$ (short form; $\mathrm{G} \alpha_{\mathrm{s} / \mathrm{olf}}-\mathrm{S}$ ) and $52 \mathrm{kDa}$ (long form; $\left.\mathrm{G} \alpha_{\mathrm{s} / \mathrm{olf}^{-}}-\mathrm{L}\right)$. The $39 \mathrm{kDa}$ band $\left(\mathrm{G} \alpha_{\mathrm{s} / \mathrm{olf}} \mathrm{P}\right)$ may represent the proteolytic fragment of $\mathrm{G} \alpha_{\mathrm{s} / \mathrm{olf}}$ [35]. c Co-immunoprecipitations of different $\mathrm{G}$ protein alpha-subunits $\left(\mathrm{G} \alpha_{\mathrm{s} / \mathrm{olf}}, \mathrm{G} \alpha_{\mathrm{q}}, \mathrm{G} \alpha_{\mathrm{i}}\right)$

represent a population of ventricular, atrial, and nodal cells, we observed the RNA expression of three members of the canonical olfactory pathway, GNAL, ADCY3 and CNGA2, whereas olfactory $C N G A 4$ and $C N G B 1$ mRNA expression was not observed. By comparing expression profiles, we concluded that the OR51E1-initiated signal transduction mechanism in cardiomyocytes differs from the canonical olfactory signaling pathway. However, we aimed to elucidate which G protein couples to OR51E1 in the human heart and could show that $\mathrm{G} \alpha_{\mathrm{s} / \mathrm{olf}}$ interacts with OR51E1 by performing co-immunoprecipitations. The antibodies against different $\mathrm{G} \alpha$ subunits pulled down protein complexes from lysates of the isolated human heart tissue. The western blots revealed that OR51E1 protein was co-precipitated with $\mathrm{G} \alpha_{\mathrm{s} /}$ olf protein. A weak band for OR51E1 is also visible in the $\mathrm{G} \alpha_{\mathrm{i}}$ sample (Fig. 5c).

We next aimed to pharmacologically characterize in vitro the nonanoic acid-induced signaling that triggers the observed negative chronotropic effect. with OR51E1 protein. The human heart lysate was immunoprecipitated (IP) with one of the indicated G proteins and detected with antibodies against the OR51E1 protein. d Representative recordings of Fura-2 loaded iCell ${ }^{\circledR}$-CMs. Co-application of nonanoic acid $(500 \mu \mathrm{M})$ and inhibitor gallein $(10 \mu \mathrm{M})$. e Quantification of nonanoic acid-induced negative chronotropic effects by pretreating with or without gallein $(10 \mu \mathrm{M})$ in $\mathrm{Ca}^{2+}$ imaging experiments. The data are shown as the mean \pm SEM $(n>40)$. Significance was calculated Student's $t$ test or Mann-Whitney $U$ test $\left({ }^{*} p<0.05,{ }^{* *} p<0.01\right.$ and $* * * p<0.001)$

In pacemaker cells of the human heart, stimulation of the muscarinic acetylcholine receptor $\mathrm{M}_{2}$ by acetylcholine or carbachol mediates negative chronotropic and inotropic effects by coupling to a PTX-sensitive G protein $\left(\mathrm{G}_{\mathrm{i}} / \mathrm{G}_{\mathrm{o}}\right)$, which results in the inhibition of adenylyl cyclase and thereby a decrease in cAMP level and protein kinase A phosphorylation [78]. Furthermore, the $\mathrm{G}_{\beta \gamma}$ subunit of the $\mathrm{G}$ protein activates $G$ protein regulated inward-rectifier potassium channels (GIRK), which cause a hyperpolarization of the cell membrane and move the sinoatrial node further from depolarization [103]. Thus, it takes longer for HCN channels to depolarize the cell, resulting in a reduced heart rate. Using the stem cell-derived cardiomyocyte model, we excluded the notion that nonanoic acid activates the muscarinic receptor pathway because the $G_{i} / G_{o}$ protein inhibitor pertussis toxin showed no effect on the nonanoic acid-induced negative chronotropic effect in $\mathrm{Ca}^{2+}$ imaging experiments (Figure S4C). However, gallein, an inhibitor of $\mathrm{G}$ protein $\beta \gamma$ subunit-dependent signaling, significantly abolished the 
nonanoic acid-induced effect, likely also via GIRK (Fig. 5d, e). This finding suggests the involvement of the G protein $\beta \gamma$ subunit and thus confirms a $G$ protein-depended pathway induced by OR51E1 in cardiomyocytes. Further $\mathrm{Ca}^{2+}$ imaging measurements under calcium-free conditions or with different established inhibitors of typical GPCR signaling effectors, such as the adenylyl cyclase (MDL12330A) or phospholipase C (U-73122), affect spontaneous $\mathrm{Ca}^{2+}$ transients, and we were therefore not able to draw any conclusion regarding the involvement of either AC or PLC in the OR51E1-initiated pathway (Figure S4D) [44].

\section{OR51E1 agonists reduce contraction force of explanted heart preparations}

To confirm the data obtained from stem cell-derived cardiomyocytes, we measured the effect of OR51E1 ligands on human cardiac tissue ex vivo. A total of 62 measurements were performed using nine different myocardial samples after periods of 1-8 days of slice cultivation. The mean developed force was $1.6 \mathrm{mN}$ among all slices. Five measurements were excluded because of pronounced reactions to DMSO. Slices derived from any of the issue specimen were found suitable for the study, regardless of the etiology of heart failure and the duration of tissue culture. The investigated fatty acids showed a clear structure-activity relationship of their efficacy and kinetics of action. These results are in accord with the receptive field of heterologously expressed OR51E1. Small-molecule fatty acids $(\mathrm{C}<9)$ typically induced a transient decrease in contractility that recovered by up to $60 \%$ over the 4 -min course of drug application. Larger molecules $(\mathrm{C}>9)$ provoked a stable impairment of contractility down to $33 \%$ of the baseline force (Fig. 6a, b; Table S2).

Additionally, we confirmed the negative inotropic effect of OR51E1 agonists observed in heart slices on trabeculae from failing ventricular human myocardium. We found a
A

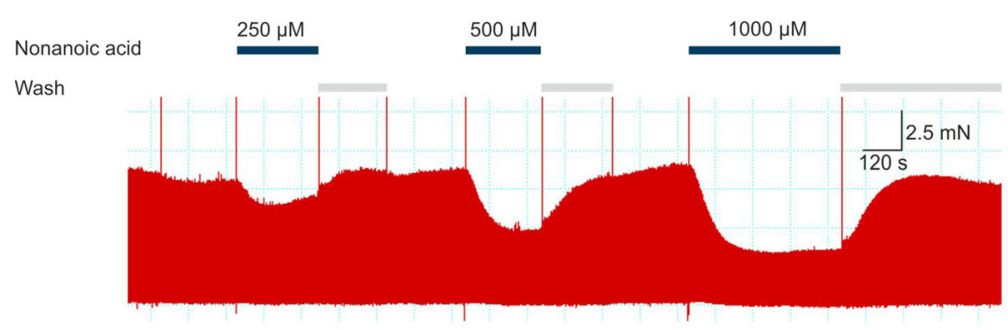

C

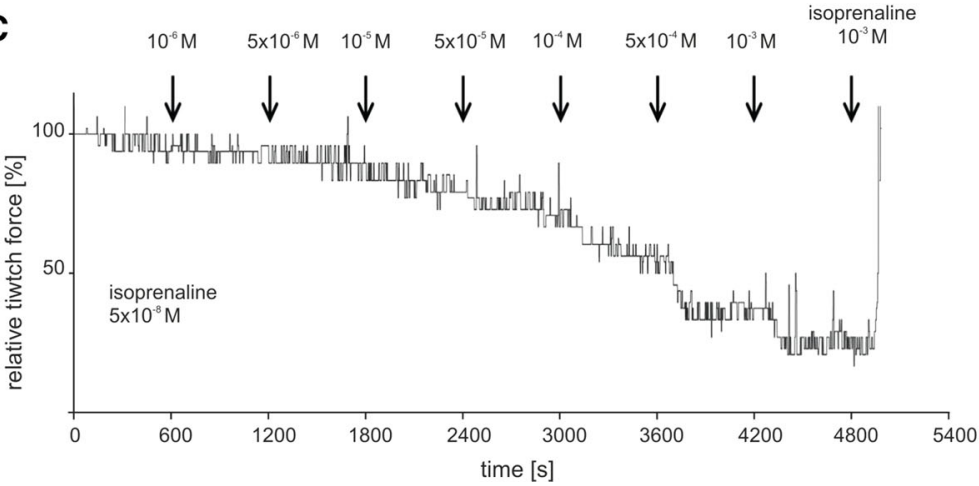

B

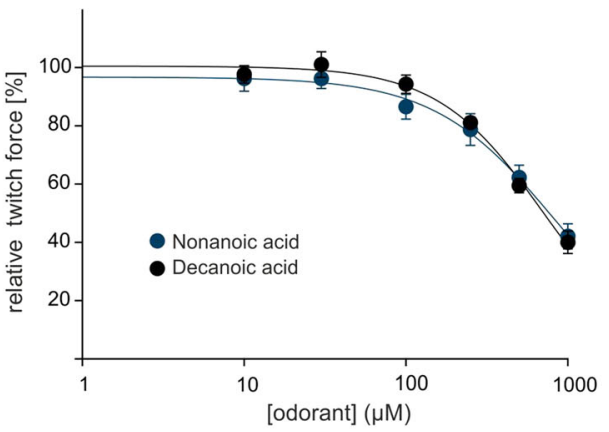

D

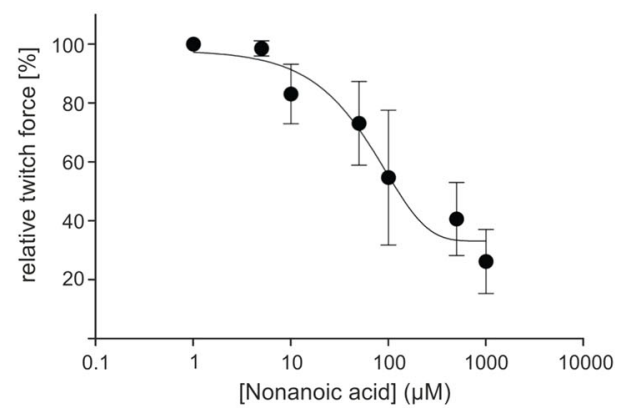

Fig. 6 Nonanoic acid induces transient negative inotropic effects in preparations of explanted human ventricles. a Representative recording of a contractile force measurement on slice preparations with OR51E1 agonist nonanoic acid. Nonanoic acid stimulation repetitively induced a dose-dependent decrease in contractile force of slice preparations (300 $\mu \mathrm{m}$ thickness) of adult human failing ventricle, which was reversible after washout. The twitch force was measured at $0.5 \mathrm{~Hz}$ electrical stimulation ( $3 \mathrm{~ms}, 50 \%$ above threshold). Application of nonanoic acid is indicated by blue horizontal bars. b The dose dependence of nonanoic acid and decanoic acid induced a decrease in the twitch force of human ventricular slice preparations. The mean of three independent preparations was calculated and normalized to the contraction force developed at $0.5 \mathrm{~Hz}$ of electric stimulation. c Representative recording of a contractile force measurement of a human ventricular trabecula with nonanoic acid. Nonanoic acid induced a decrease in the isometric contraction force of a human ventricular trabecula. Force levels were normalized to the maximum response to isoprenaline $\left(5 \times 10^{-8} \mathrm{M}\right)$ prior to nonanoic acid stimulation. Application of isoprenaline at the end of each experiment served to control trabecula viability. d Dose dependence of nonanoic acid-induced decrease in isometric twitch force tested on three ventricular trabeculae preparations. Each point represents the mean decrease in contractile amplitude measured as percentage of the response to isoprenaline $\left(5 \times 10^{-8} \mathrm{M}\right)$ prior to nonanoic acid stimulation. Error bars represent the SEM 
dose-dependent reduction in the isometric twitch force of isoproterenol stimulated trabeculae under the influence of nonanoic acid; the force was similar to that observed in heart slices and stem cell-derived cardiomyocytes (Fig. 6c, d).

\section{Possible OR51E1 agonists are present in human epicardial tissue and are elevated in plasma of diabetic patients}

To identify the endogenous ligand for OR51E1, we investigated the fatty acid profiles and concentrations in human plasma and epicardial adipose tissue. High-resolution gas chromatographic analysis detected the free fatty acid (FFA) OR51E1 agonists dodecanoic acid (C12:0) and tetradecanoic acid (C14:0) in the plasma of normal controls at low concentrations. Notably, all medium-chain (C:9$\mathrm{C}: 13)$ free fatty acid concentrations showed an approximately twofold increase in diabetic patients compared with non-diabetic controls. (Table 1a). However, plasma free fatty acid concentrations may not reflect the situation in epicardial adipose tissue. Therefore, we determined the concentration of the free fatty acids in total epicardial adipose tissue (Table 1b). We found approximately 2, 4, 11 and $23 \mu \mathrm{mol} / 1$ for C9:0, C10:0, C11:0 and C12:0, respectively, for non-diabetic subjects. Since FFAs are mainly present in the aqueous fraction of adipose tissue and since adipose tissue contains approximately $10 \%$ water, the interstitial FFA concentrations are about ten times higher, thus in receptor-activating quantities, whereas the identified receptor antagonist was not detected. The fatty acid profile in triacylglycerides in epicardial tissue also demonstrated the presence of OR51E1-activating fatty acids with, however, no difference between diabetic and non-diabetic subjects (Table 1c). Our findings provide the first hints of an involvement of OR51E1 in the regulation of cardiac function by circulating OR51E1-activating FFA and/or by FFA released from epicardial adipose tissue.

\section{Discussion}

\section{Expression of OR51E1 in the human heart}

A variety of ORs are expressed in diverse non-olfactory human tissues, including the brain, the lung, the kidney and the prostate $[25,28,98,115]$. However, the functional role of these ORs has only been investigated in a few tissues $[8,67,90,99,114]$. OR51E1 was primarily identified in the prostate and is overexpressed in prostate cancer [31, 104, 105]. Further studies have demonstrated the expression of OR51E1 in various healthy and pathologically altered tissues, whereas the function still remains unknown [19, 28, 34, 50].
In the human heart, a broad spectrum of ORs was detected at the RNA level, whereas the odorant receptor OR51E1 was identified as the highest expressed OR by transcriptome analysis [28]. In addition, our transcriptome analysis results showed that OR51E1 is also the highest expressed OR in the human fetal heart. The prenatal expression of ectopic OR was described for the rodent developing heart, suggesting a potential role during cardiac development, and for avian embryos, indicating an important role in cell recognition during embryogenesis [22, 23, 26]. The occurrence of OR51E1 mRNA during the early stages of fetal development suggests a possible role in heart development. In this study, we focused on the expression of OR51E1 in the adult human cardiac ventricles and stem cell-derived cardiomyocytes, which we used as a cardiac in vitro model for the functional analysis of the odorant receptor OR51E1 at the cellular and molecular levels. We detected transcripts of OR51E1 by RT-PCR in human heart tissue and stem cell-derived cardiomyocytes but not in pluripotent stem cells. Additionally, the expression of OR51E1 could also be validated at the protein level in human heart tissue by immunocytochemical analysis and western blot. Compared to prostate tissue, in the human heart tissue we detected beside the monomeric form of OR51E1 also receptor oligomeres. The detection of higher molecular weight receptor dimers and oligomers are features commonly found after SDS-PAGE for ORs and for GPCR in general $[6,17,66,100,107]$. The physiological significance of OR oligomerization is still unknown. Interestingly, different oligomerization states can be observed for the same receptor also in other tissues. The OR51E1 paralogous olfactory receptor 51E2 was found as monomer in the prostate and in human pigment cells in a monomeric and dimeric form $[33,67]$.

\section{Activation of OR51E1 in cardiomyocytes}

We observed that stimulation of cardiomyocytes with OR51E1 agonist leads to inhibition of the spontaneous $\mathrm{Ca}^{2+}$ transients. We showed that this negative chronotropic effect is dose-dependent over the micromolar-to-millimolar range. Detailed analysis revealed that regardless of which type of stem cell-derived cardiomyocytes (hESC- and hIPSCderived) was investigated, the nonanoic acid-induced effect remained unchanged. We tested whether other mediumchain fatty acids (MCFA) also reduce the frequency of $\mathrm{Ca}^{2+}$ spikes and found that the OR51E1 agonists decanoic, dodecanoic and tetradecanoic acid elicited similar effects, whereas compounds that were inactive on the heterologously expressed OR51E1 did not affect the $\mathrm{Ca}^{2+}$ spike frequency.

We next aimed to investigate the OR51E1-induced signaling cascade. In olfactory receptor neurons, activation of an olfactory receptor leads to an activation of adenylyl 
Table 1 Composition and concentration of fatty acids in plasma and epicardial adipose tissue

\begin{tabular}{lccc}
\hline Fatty acid & Control & Diabetic & $p$ value \\
\hline (A) Plasma free fatty acid concentration $(\mu \mathrm{mol} / \mathrm{l})$ in controls & $(n=19)$ and diabetic patients $(n=27)$ \\
Nonanoic acid (C9:0) & $0.06 \pm 0.03$ & $0.16 \pm 0.06$ & $<0.0001$ \\
Decanoic acid (C10:0) & $0.93 \pm 0.88$ & $2.3 \pm 1.2$ & $<0.0001$ \\
Undecanoic acid (C11:0) & $0.20 \pm 0.15$ & $0.4 \pm 0.15$ & $<0.0001$ \\
Dodecanoic acid (C12:0) & $3.6 \pm 1.8$ & $6.3 \pm 2.5$ & $<0.0001$ \\
Tridecanoic acid (C13:0) & $0.53 \pm 0.35$ & $0.97 \pm 0.63$ & 0.0151 \\
Tetradecanoic acid (C14:0) & $12.2 \pm 4.2$ & $14.9 \pm 8.8$ & 0.3408 \\
Pentadecanoic acid (C15:0) & $1.9 \pm 0.62$ & $2.7 \pm 1.9$ & 0.1268 \\
Palmitic acid (C16:0) & $110 \pm 29.9$ & $123 \pm 58.4$ & 0.7364 \\
Stearic acid (C18:0) & $50.4 \pm 10.5$ & $59.4 \pm 23.3$ & 0.9071 \\
Oleic acid (C18:1N9) & $164 \pm 51.8$ & $166 \pm 109$ & 0.3403 \\
\hline Fatty acid & Non-diabetic & Diabetic & $p$ value \\
\hline
\end{tabular}

(B) Epicardial adipose tissue free fatty acid concentration (nmol/g tissue wet weight) in controls $(n=12)$ and diabetic patients $(n=15)$

\begin{tabular}{llll} 
Nonanoic acid (C9:0) & $18.2 \pm 8.3$ & $27.7 \pm 15.9$ & 0.0736 \\
Decanoic acid (C10:0) & $40.8 \pm 45$ & $37.1 \pm 57.8$ & 0.8524 \\
Undecanoic acid (C11:0) & $106 \pm 27$ & $105 \pm 59.3$ & 0.9738 \\
Dodecanoic acid (C12:0) & $214 \pm 215$ & $160 \pm 228$ & 0.5389 \\
Tridecanoic acid (C13:0) & $7.4 \pm 4.5$ & $7.2 \pm 3.9$ & 0.9363 \\
Tetradecanoic acid (C14:0) & $381 \pm 290$ & $225 \pm 236$ & 0.1376 \\
Pentadecanoic acid (C15:0) & $90 \pm 120$ & $23.5 \pm 16$ & 0.0426 \\
Palmitic acid (C16:0) & $1716 \pm 760$ & $1155 \pm 760$ & 0.0680 \\
Stearic acid (C18:0) & $566 \pm 140$ & $516 \pm 174$ & 0.4239 \\
Oleic acid (C18:1N9) & $1948 \pm 914$ & $1285 \pm 899$ & 0.0701 \\
\hline Fatty acid & Non-diabetic & Diabetic & $p$ value \\
\hline C) Fatty acid profile of triacylglycerides of epicardial adipose tissue in non-diabetic $(n=15)$ and \\
patients $(n=14)$. Fatty acid composition is expressed as percentage of all fatty acids shown \\
Nonanoic acid (C9:0) & $0.009 \pm 0.003$ & $0.01 \pm 0.009$ & 0.4941 \\
Decanoic acid (C10:0) & $0.15 \pm 0.06$ & $0.17 \pm 0.08$ & 0.5801 \\
Undecanoic acid (C11:0) & $0.15 \pm 0.04$ & $0.2 \pm 0.11$ & 0.6464 \\
Dodecanoic acid (C12:0) & $1.1 \pm 0.37$ & $1.3 \pm 0.37$ & 0.2278 \\
Tridecanoic acid (C13:0) & $0.03 \pm 0.01$ & $0.03 \pm 0.006$ & 0.7175 \\
Tetradecanoic acid (C14:0) & $4.8 \pm 1.0$ & $4.9 \pm 0.96$ & 0.6269 \\
Pentadecanoic acid (C15:0) & $0.38 \pm 0.13$ & $0.43 \pm 0.08$ & 0.1491 \\
Palmitic acid (C16:0) & $28.9 \pm 1.8$ & $29.1 \pm 2.0$ & 0.8250 \\
Stearic acid (C18:0) & $7.2 \pm 1.9$ & $6.4 \pm 1.6$ & 0.2935 \\
Oleic acid (C18:1N9) & $57.3 \pm 3.3$ & $57.5 \pm 2.5$ & 0.8490
\end{tabular}

Data were presented as mean $\pm \mathrm{SD}$. Non-normally distributed data were transformed to the logarithmic scale for statistical analysis. The comparison of mean variables between groups was carried out using means-independent simple $t$ test. $p<0.05$ was considered statistically significant cyclase III via the $\mathrm{G} \alpha_{\text {olf }}$ protein. AC-III, in turn, is activated via cAMP CNG-channels [3, 45, 65]. The OR signal transduction pathway in non-olfactory tissues appears to vary depending on the tissue. For most non-olfactory tissues, which express ORs, the initiated pathway is still unknown, but the few examples of pathways that have been determined differ from the classical olfactory signaling cascade [8, 13, 89].
Our results suggest that OR51E1 couples predominantly to the stimulatory $G$ protein, probably to the olfactory $G$ protein. Moreover, the inhibitory $\mathrm{G}$ protein could also be a putative interaction partner of OR51E1 due to the finding that $\mathrm{G} \alpha_{i}$ protein was weakly co-precipitated with OR51E1 protein. Recently, it was shown that beside $\mathrm{G} \alpha_{\text {olf }}$ also $\mathrm{G} \alpha_{\mathrm{o}}$ is functionally coupled to ORs in olfactory sensory neurons [84]. 
Furthermore, we could observe the involvement of the $\beta \gamma$ subunit of the $G$ protein in the nonanoic acid-induced effect. The $G$ protein $\beta \gamma$ subunits interact with effector molecules, such as phospholipases, adenylyl cyclase and ion channels, in a manner that leads to their activation or inhibition [16]. Therefore, it is not surprising that the $\beta \gamma$ subunit is discussed as a drug target, inter alia, for preventing heart failure $[53,88]$. OR signaling via $\beta \gamma$ subunits was previously described in olfactory sensory neurons and was also demonstrated for ectopically expressed OR51E2, a paralog of OR51E1, in prostate cancer cells $[82,96]$. Classical cardiac GPCRs such as the muscarinic acetylcholine receptor $\mathrm{M} 2$ and adrenergic receptors also act via the $\beta \gamma$ subunit in the heart [87]. Interestingly, bitter taste receptor agonists elicit $G$ protein $\beta \gamma$-dependent negative inotropy in the murine heart [29]. Thus, we suggest that OR51E1 activation leads to GIRK channel opening via $\mathrm{G}_{\beta \gamma}$ subunit. This opening leads to a hyperpolarization of the cell, which counteracts the HCN channel-induced depolarization, resulting in a reduction of the $\mathrm{Ca}^{2+}$ spike frequency.

However, we could not deduce whether the interaction between $G$ protein $\beta \gamma$ subunits and other effector molecules primarily mediates the negative chronotropic effect or if the $G \beta \gamma$ subunit only enhances the effect without playing a key role.

We also found that OR51E1 agonists evoked negative inotropic effects on explanted heart preparations. The reduction of contractility of adult human myocardium stimulated with MCFA was dose-dependent and occurred over a similar dose range as the negative chronotropic effect in stem cell-derived cardiomyocytes, possibly indicating the involvement of a similar $\mathrm{G}$ protein $\beta \gamma$-mediated signal transduction. It is well recognized that $\beta \gamma$ subunits contribute to the depression of contractility in failing myocardium by targeting the $\beta$-adrenergic receptor kinase to the membrane-bound receptors, thereby mediating autologous $\beta$-receptor desensitization [74, 83, 85]. However, it is unlikely that this mechanism would be responsible for the reduction in contractility provoked by MCFA in our study because these responses developed with fast kinetics and in the absence of exogenous $\beta$-receptor stimulation. There are alternative targets by which $\mathrm{G}$ protein $\beta \gamma$-subunits reduce contractility of failing myocardium in a manner independently of $\beta$-receptor sensitization [52]. G protein $\beta \gamma$-coupled receptors may activate phospholipase C- $\beta$, ERK1/2 and PI3-kinase $\gamma$ isoform $[46,64]$, the latter of which has been identified as a negative regulator of cardiac contractility [18]. It is, therefore, tempting to speculate that the negative inotropic effect of the $G$ protein $\beta \gamma$-coupled OR51E1 receptor may be mediated by PI3kinase $\gamma$ activation. In addition, it should be noted that the measurements were conducted with myocardium of patients with a heart failure. Human healthy heart tissue was not available in this study due to practical and ethical limitations. Therefore, we could not ensure that cardiac diseases influence the nonanoic acid-induced effect.

\section{Possible role of OR51E1 in the heart}

De-orphanization studies on the recombinant OR51E1 revealed nonanoic acid, which has an unpleasant rancid odor, as an activating ligand $[1,80]$. In the present study, we could identify, in addition to nonanoic acid, several MCFA as specific OR51E1 activator. The specificity of recombinant OR51E1 for MCFA was determined by testing a verity of structurally related substances that did not activate the receptor. OR51E1-activating MCFA consist of a 4-14 carbon chain and are mainly provided by food digestion and lipolysis in adipose tissue. In contrast to long-chain fatty acids (LCFA), the dietary intake of shortand medium-chain fatty acids are not significantly associated with the risk of coronary heart disease [41]. A number of studies have indicated that fatty acids not only serve as energy sources but can also act as signaling molecules $[43,68]$.

We determined the fatty acid profile in human plasma and epicardial adipose tissue as a potential storage site for OR51E1-activating FFA. Recent data indicate a possible role of adipose tissue in modulating cardiac function $[12,42,69]$. It was reported that cardiac adipocytes are able to release substances that suppress the contraction of cardiomyocytes by attenuating intracellular $\mathrm{Ca}^{2+}$ levels [49]. We detected medium-chain free fatty acids, which may act as OR51E1 agonists in epicardial adipose tissue. $\mathrm{We}$, therefore, hypothesize that, in addition to dietary intake, OR51E1-activating MCFA in plasma may be released from adipocytes. In plasma of diabetic patients medium-chain free fatty acid concentrations were elevated, whereas the fatty acid profile of triacylglyceride in the fat compartment was not different between both groups. Previously, the fatty profile in epicardial adipose tissue has been determined; however, the MCFA content has not been reported in detail [73]. Thus, OR51E1 is one of the few deorphanized ORs with an odorant that is also present in the human body.

A great number of reports have shown that FFA-sensing GPCRs play important roles in mediating a variety of physiological processes, such as regulation of energy metabolism mediated by the secretion of hormones and by the regulation of the sympathetic nerve systems and taste preferences, and have demonstrated potential as therapeutic targets for various metabolic and inflammatory disorders, including obesity, type 2 diabetes, atherosclerosis, cardiovascular diseases, ulcerative colitis, Crohn's disease and irritable bowel disease [5, 21, 38, 43, 61, 91, 93, 97]. 
OR51E1 is the highest expressed orphan MCFA-sensing receptor according to our transcriptome data (Table S3). The ligand spectrum of the free fatty acid receptors (FFAR) known to date is only partially overlapping with that of OR51E1. Among the FFAR family, FFAR1 (known as GPR40) and FFAR4 (known as GPR120 and O3FAR1) are classified as medium- to long-chain fatty acid-activated receptors (FFAR1: > C12; FFAR4: C14-C18) [9, 40]. FFAR2 and FFAR3 (known as GPR43 and GPR41) respond to short-chain fatty acids that have fewer than five carbon atoms [10]. Nonetheless, a potential role of FFAR4 in the cardioprotective effect of eicosapentaenoic acid was recently described [24]. Only the free fatty acid receptor GPR84 (C9-C14) is activated by nonanoic acid, whereby nonanoic acid displays the weakest ligand [102]. According to our transcriptome analysis and as previously described, all five receptors are not or only very weakly expressed on mRNA level in the human ventricular myocardium [40]. Because the OR51E1 antagonist and knockdown experiments abolished the nonanoic acid-induced effect completely, we propose that the observed action of MCFA on cardiomyocytes is primarily mediated by OR51E1, but the involvement of other FFARs in sensing OR51E1-activating MCFA cannot be fully excluded in an in vivo situation.

Effects of MCFA on cardiac function were previously reviewed by Francois Labarthe and colleagues [47]. The authors suggested that MCFA not only provide a highly efficient source of energy production as contrary to LCFA they enter the cells by free diffusion and are preferentially directed toward oxidation rather than storage. MCFA also may positively modulate cardiac disease progression when considering the heart's energy status and contractile dysfunction. In animal heart models, MCFA were reported to improve diabetic cardiomyopathy, prevent cardiac hypertrophy and recover metabolism and contractile function after transient ischemia [2, 15, 27, 48, 55, 63]. The role of OR51E1 in MCFA-mediated benefits for cardiac function or disease progression remains elusive but would be interesting to examine in further studies. Moreover, polyunsaturated fatty acids (PUFAs), such as arachidonic and eicosapentaenoic acid, have been shown to affect $\mathrm{Ca}^{2+}$ handling of cardiomyocytes in vitro [54, 57, 110]. PUFAs induce negative inotropy and inhibit $\mathrm{Ca}^{2+}$ transients, which leads to the consideration of PUFAs as antiarrhythmic agents. Furthermore, arachidonic acid was described to counteract $\beta$-adrenergic receptor-induced stimulation and was consequently considered to perform a cardiac protective function [57, 72].

The results of this study indicate at negative inotropic effects of OR51E1 activation in vivo, however, do not allow for straightforward interpretation of a clinical relevance as further preclinical and eventually clinical evaluation are required to qualify OR51E1 as a cardiovascular drug target. Preclinical testing in animal models should be conducted in future studies.

Interestingly, the OR51E1 and OR51E2 mouse orthologs were found to be expressed in the carotid body and the OR51E2 mouse ortholog, namely Olfr78, acts as a hypoxia sensor. A decreasing oxygen level leads to the production of lactate that in turn affects the breathing circulation via Olfr78 [14]. This finding represents an alternative physiological function of an OR by detecting an endogenous ligand. In the human heart, OR51E1 may act as dietary sensor, which may influence the mechanical and electrical heart function and may possibly be involved in the regulation of the energy metabolism.

In conclusion, our data demonstrate a significant progress towards the characterization of the functional role of ORs in the human heart. We could show that activation of OR51E1 by MCFA induces negative inotropy in human explanted heart preparations and leads to negative chronotropy in stem cell-derived cardiomyocytes, which could be reversed by our identified OR51E1 antagonist. Based on our results, we hypothesize that OR51E1 may play a role in the metabolic regulation of cardiac function. The involvement of heart diseases in pathophysiological processes can only be speculated in the absence of data from animal models or patient studies.

Acknowledgements We thank Simon Pyschny and Franziska Moessler for helpful technical assistance. Nikolina Jovancevic and Lea Weber were funded by the Heinrich und Alma Vogelsang Stiftung. Hanns Hatt was funded by the DFG-Sonderforschungsbereich 642 "GTP- and ATP dependent membrane processes". Hendrik Milting was supported by the Erich and Hanna Klessmann-Stiftung, Guetersloh, Germany. Hendrik Milting and Andreas Dendorfer were supported by DZHK-Grant 81 X2600217.

\section{Compliance with ethical standards}

Conflict of interest The authors declare that they have no conflict of interest.

Open Access This article is distributed under the terms of the Creative Commons Attribution 4.0 International License (http://crea tivecommons.org/licenses/by/4.0/), which permits unrestricted use, distribution, and reproduction in any medium, provided you give appropriate credit to the original author(s) and the source, provide a link to the Creative Commons license, and indicate if changes were made.

\section{References}

1. Adipietro KA, Mainland JD, Matsunami H, Zhang J (2012) Functional evolution of mammalian odorant receptors. PLoS Genet 8:e1002821. doi:10.1371/journal.pgen.1002821

2. Allard MF, Parsons HL, Saeedi R, Wambolt RB, Brownsey R (2006) AMPK and metabolic adaptation by the heart to pressure 
overload. Am J Physiol Heart Circ Physiol 292:H140-H148. doi:10.1152/ajpheart.00424.2006

3. Bakalyar HA, Reed RR, Bakalyar H, Reed R (1990) Identification of a specialized adenylyl cyclase that may mediate odorant detection. Science 250:1403-1406. doi:10.1126/science. 2255909

4. Ben-Arie N, Lancet D, Taylor C, Khen M, Walker N, Ledbetter DH, Carrozzo R, Patel K, Sheer D, Lehrach H, North MA (1994) Olfactory receptor gene cluster on human chromosome 17. Possible duplication of an ancestral receptor repertoire. Hum Mol Genet 3:229-235. doi:10.1093/hmg/3.2.229

5. Bindels LB, Dewulf EM, Delzenne NM (2013) GPR43/FFA2: physiopathological relevance and therapeutic prospects. Trends Pharmacol Sci 34:226-232. doi:10.1016/j.tips.2013.02.002

6. Boekhoff I, Schleicher S, Strotmann J, Breer H (1992) Odorinduced phosphorylation of olfactory cilia proteins. Proc Natl Acad Sci USA 89:11983-11987. doi:10.1073/pnas.89.24.11983

7. Brandenburger M, Wenzel J, Bogdan R, Richardt D, Nguemo F, Reppel M, Hescheler J, Terlau H, Dendorfer A (2011) Organotypic slice culture from human adult ventricular myocardium. Cardiovasc Res 93:50-59. doi:10.1093/cvr/cvr259

8. Braun T, Voland P, Kunz L, Prinz C, Gratzl M (2007) Enterochromaffin cells of the human gut: sensors for spices and odorants. Gastroenterology 132:1890-1901. doi:10.1053/j.gas tro.2007.02.036

9. Briscoe CP, Peat AJ, McKeown SC, Corbett DF, Goetz AS, Littleton TR, McCoy DC, Kenakin TP, Andrews JL, Ammala C, Fornwald JA, Ignar DM, Jenkinson S (2006) Pharmacological regulation of insulin secretion in MIN6 cells through the fatty acid receptor GPR40: identification of agonist and antagonist small molecules. Br J Pharmacol 148:619-628. doi:10.1038/sj. bjp. 0706770

10. Brown AJ, Goldsworthy SM, Barnes AA, Eilert MM, Tcheang L, Daniels D, Muir AI, Wigglesworth MJ, Kinghorn I, Fraser NJ, Pike NB, Strum JC, Steplewski KM, Murdock PR, Holder JC, Marshall FH, Szekeres PG, Wilson S, Ignar DM, Foord SM, Wise A, Dowell SJ (2003) The orphan G protein-coupled receptors GPR41 and GPR43 are activated by propionate and other short chain carboxylic acids. J Biol Chem 278:11312-11319. doi:10.1074/jbc.M211609200

11. Buck L, Axel R (1991) A novel multigene family may encode odorant receptors. A molecular basis for odor recognition. Cell 65:175-187. doi:10.1016/0092-8674(91)90418-X

12. Burgeiro A, Fuhrmann A, Cherian S, Espinoza D, Jarak I, Carvalho RA, Loureiro M, Patrício M, Antunes M, Carvalho E (2016) Glucose uptake and lipid metabolism are impaired in epicardial adipose tissue from heart failure patients with or without diabetes. Am J Physiol Endocrinol Metab 310:E550E564. doi:10.1152/ajpendo.00384.2015

13. Busse D, Kudella P, Grüning N, Gisselmann G, Ständer S, Luger T, Jacobsen F, Steinsträßer L, Paus R, Gkogkolou P, Böhm M, Hatt H, Benecke H (2014) A synthetic sandalwood odorant induces wound-healing processes in human keratinocytes via the olfactory receptor OR2AT4. J Invest Dermatol 134:2823-2832. doi:10.1038/jid.2014.273

14. Chang AJ, Ortega FE, Riegler J, Madison DV, Krasnow MA (2015) Oxygen regulation of breathing through an olfactory receptor activated by lactate. Nature 527:240-244. doi:10.1038/ nature 15721

15. Chatham JC, Forder JR (1997) Relationship between cardiac function and substrate oxidation in hearts of diabetic rats. Am J Physiol 273:H52-H58

16. Clapham DE, Neer EJ (1997) G protein $\beta \gamma$ subunits. Annu Rev Pharmacol Toxicol 37:167-203. doi:10.1146/annurev.pharmtox. 37.1.167
17. Cook BL, Steuerwald D, Kaiser L, Graveland-Bikker J, Vanberghem M, Berke AP, Herlihy K, Pick H, Vogel H, Zhang S (2009) Large-scale production and study of a synthetic G proteincoupled receptor: human olfactory receptor 17-4. Proc Natl Acad Sci USA 106:11925-11930. doi:10.1073/pnas.0811089106

18. Crackower MA, Oudit GY, Kozieradzki I, Sarao R, Sun H, Sasaki T, Hirsch E, Suzuki A, Shioi T, Irie-Sasaki J, Sah R, Cheng HM, Rybin VO, Lembo G, Fratta L, Oliveira-dos-Santos AJ, Benovic JL, Kahn CR, Izumo S, Steinberg SF, Wymann MP, Backx PH, Penninger JM, Kahn C (2002) Regulation of myocardial contractility and cell size by distinct PI3 K-PTEN signaling pathways. Cell 110:737-749. doi:10.1016/S00928674(02)00969-8

19. Cui T, Tsolakis AV, Li S, Cunningham JL, Lind T, Öberg K, Giandomenico V (2013) Olfactory receptor 51E1 protein as a potential novel tissue biomarker for small intestine neuroendocrine carcinomas. Eur J Endocrinol 168:253-261. doi:10. 1530/EJE-12-0814

20. DeWire SM, Violin JD (2011) Biased ligands for better cardiovascular drugs: dissecting G-protein-coupled receptor pharmacology. Circ Res 109:205-216. doi:10.1161/CIRCRESAHA. 110.231308

21. Dranse HJ, Kelly MEM, Hudson BD (2013) Drugs or diet?Developing novel therapeutic strategies targeting the free fatty acid family of GPCRs. Br J Pharmacol 170:696-711. doi:10. 1111/bph.12327

22. Dreyer WJ (1998) The area code hypothesis revisited. Olfactory receptors and other related transmembrane receptors may function as the last digits in a cell surface code for assembling embryos. Proc Natl Acad Sci USA 95:9072-9077. doi:10.1073/ pnas.95.16.9072

23. Drutel G, Arrang JM, Diaz J, Wisnewsky C, Schwartz K, Schwartz JC (1995) Cloning of OL1, a putative olfactory receptor and its expression in the developing rat heart. Recept Channels 3:33-40

24. Eclov JA, Qian Q, Redetzke R, Chen Q, Wu SC, Healy CL, Ortmeier SB, Harmon E, Shearer GC, O'Connell TD (2015) EPA, not DHA, prevents fibrosis in pressure overload-induced heart failure: potential role of free fatty acid receptor 4 . J Lipid Res 56:2297-2308. doi:10.1194/jlr.M062034

25. Feldmesser E, Olender T, Khen M, Yanai I, Ophir R, Lancet D (2006) Widespread ectopic expression of olfactory receptor genes. BMC Genom 7:121. doi:10.1186/1471-2164-7-121

26. Ferrand N, Pessah M, Frayon S, Marais J, Garel JM (1999) Olfactory receptors, Golf alpha and adenylyl cyclase mRNA expressions in the rat heart during ontogenic development. J Mol Cell Cardiol 31:1137-1142. doi:10.1006/jmcc.1999.0945

27. Finck BN, Han X, Courtois M, Aimond F, Nerbonne JM, Kovacs A, Gross RW, Kelly DP (2003) A critical role for PPARalpha-mediated lipotoxicity in the pathogenesis of diabetic cardiomyopathy: modulation by dietary fat content. Proc Natl Acad Sci USA 100:1226-1231. doi:10.1073/pnas.0336724100

28. Flegel C, Manteniotis S, Osthold S, Hatt H, Gisselmann G (2013) Expression profile of ectopic olfactory receptors determined by deep sequencing. PLoS One 8:e55368. doi:10.1371/ journal.pone. 0055368

29. Foster SR, Blank K, See Hoe LE, Behrens M, Meyerhof W, Peart JN, Thomas WG (2014) Bitter taste receptor agonists elicit G-protein-dependent negative inotropy in the murine heart. Faseb J 28:4497-4508. doi:10.1096/fj.14-256305

30. Foster SR, Roura E, Molenaar P, Thomas WG (2015) G proteincoupled receptors in cardiac biology. Old and new receptors. Biophys Rev 7:77-89. doi:10.1007/s12551-014-0154-2

31. Fuessel S, Weigle B, Schmidt U, Baretton G, Koch R, Bachmann M, Rieber EP, Wirth MP, Meye A (2006) Transcript 
quantification of Dresden G protein-coupled receptor (D-GPCR) in primary prostate cancer tissue pairs. Cancer Lett 236:95-104. doi:10.1016/j.canlet.2005.05.005

32. Fujita Y, Takahashi T, Suzuki A, Kawashima K, Nara F, Koishi R (2007) Deorphanization of Dresden G protein-coupled receptor for an odorant receptor. J Recept Signal Transduct Res 27:323-334. doi:10.1080/10799890701534180

33. Gelis L, Jovancevic N, Veitinger S, Mandal B, Arndt H, Neuhaus EM, Hatt $H$ (2016) Functional characterization of the odorant receptor 51E2 in human melanocytes. J Biol Chem 291:17772-17786. doi:10.1074/jbc.M116.734517

34. Giandomenico V, Cui T, Grimelius L, Oberg K, Pelosi G, Tsolakis AV (2013) Olfactory receptor 51E1 as a novel target for diagnosis in somatostatin receptor-negative lung carcinoids. J Mol Endocrinol 51:277-286. doi:10.1530/JME-13-0144

35. Giusti L, Taddei S, Ceccarelli F, Chericoni S, Bigini G, Lucacchini A, Mazzoni MR (2003) Alkylation of sulfhydryl groups on Galpha(s/olf) subunits by $N$-ethylmaleimide: regulation by guanine nucleotides. Biochim Biophys Acta 1613:7-14

36. Glusman G, Bahar A, Sharon D, Pilpel Y, White J, Lancet D (2000) The olfactory receptor gene superfamily. Data mining, classification, and nomenclature. Mamm Genome 11:1016-1023. doi:10.1007/s003350010196

37. Go AS, Mozaffarian D, Roger VL, Benjamin EJ, Berry JD, Blaha MJ, Dai S, Ford ES, Fox CS, Franco S, Fullerton HJ, Gillespie C, Hailpern SM, Heit JA, Howard VJ, Huffman MD, Judd SE, Kissela BM, Kittner SJ, Lackland DT, Lichtman JH, Lisabeth LD, Mackey RH, Magid DJ, Marcus GM, Marelli A, Matchar DB, McGuire DK, Mohler ER, Moy CS, Mussolino ME, Neumar RW, Nichol G, Pandey DK, Paynter NP, Reeves MJ, Sorlie PD, Stein J, Towfighi A, Turan TN, Virani SS, Wong ND, Woo D, Turner MB (2014) Executive summary: heart disease and stroke statistics-2014 update: a report from the American Heart Association. Circulation 129:399-410. doi:10. 1161/01.cir.0000442015.53336.12

38. Hara T, Ichimura A, Hirasawa A (2014) Therapeutic role and ligands of medium- to long-chain fatty acid receptors. Front Endocrinol 5:107. doi:10.3389/fendo.2014.00083

39. Hescheler J, Kameyama M, Trautwein W (1986) On the mechanism of muscarinic inhibition of the cardiac Ca current. Pflugers Arch 407:182-189. doi:10.1007/BF00580674

40. Hirasawa A, Tsumaya K, Awaji T, Katsuma S, Adachi T, Yamada M, Sugimoto Y, Miyazaki S, Tsujimoto G (2004) Free fatty acids regulate gut incretin glucagon-like peptide-1 secretion through GPR120. Nat Med 11:90-94. doi:10.1038/nm1168

41. Hu FB, Stampfer MJ, Manson JE, Ascherio A, Colditz GA, Speizer FE, Hennekens CH, Willett WC (1999) Dietary saturated fats and their food sources in relation to the risk of coronary heart disease in women. Am J Clin Nutr 70:1001-1008

42. Iacobellis G, Sharma AM (2007) Epicardial adipose tissue as new cardio-metabolic risk marker and potential therapeutic target in the metabolic syndrome. Curr Pharm Des 13:2180-2184. doi:10.2174/138161207781039670

43. Ichimura A, Hasegawa S, Kasubuchi M, Kimura I (2014) Free fatty acid receptors as therapeutic targets for the treatment of diabetes. Front Pharmacol 5:226. doi:10.3389/fphar.2014.00236

44. Itzhaki I, Rapoport S, Huber I, Mizrahi I, Zwi-Dantsis L, Arbel G, Schiller J, Gepstein L (2011) Calcium handling in human induced pluripotent stem cell derived cardiomyocytes. PLoS One 6:e18037. doi:10.1371/journal.pone.0018037

45. Jones DT, Reed R (1989) Golf: an olfactory neuron specific-G protein involved in odorant signal transduction. Science 244:790-795

46. Kamal FA, Smrcka AV, Blaxall BC (2011) Taking the heart failure battle inside the cell: small molecule targeting of $G \beta \gamma$ subunits. J Mol Cell Cardiol 51:462-467. doi:10.1016/j.yjmcc. 2011.01.006

47. Labarthe F, Gélinas R, Des Rosiers C (2008) Medium-chain fatty acids as metabolic therapy in cardiac disease. Cardiovasc Drugs Ther 22:97-106. doi:10.1007/s10557-008-6084-0

48. Labarthe F, Khairallah M, Bouchard B, Stanley WC, Des Rosiers C (2005) Fatty acid oxidation and its impact on response of spontaneously hypertensive rat hearts to an adrenergic stress: benefits of a medium-chain fatty acid. Am J Physiol Heart Circ Physiol 288:H1425-H1436. doi:10.1152/ajpheart.00722.2004

49. Lamounier-Zepter V (2006) Human adipocytes attenuate cardiomyocyte contraction: characterization of an adipocytederived negative inotropic activity. Faseb J 20:1653-1659. doi:10.1096/fj.05-5436com

50. Leja J, Essaghir A, Essand M, Wester K, Öberg K, Tötterman TH, Lloyd R, Vasmatzis G, Demoulin J, Giandomenico V (2008) Novel markers for enterochromaffin cells and gastrointestinal neuroendocrine carcinomas. Mod Pathol 22:261-272. doi: $10.1038 /$ modpathol.2008.174

51. Li YR, Matsunami H (2011) Activation state of the M3 muscarinic acetylcholine receptor modulates mammalian odorant receptor signaling. Sci Signal 4:ra1. doi:10.1126/scisignal. 2001230

52. Li Z, Laugwitz K, Pinkernell K, Pragst I, Baumgartner C, Hoffmann E, Rosport K, Münch G, Moretti A, Humrich J, Lohse MJ, Ungerer M (2003) Effects of two Gbetagamma-binding proteins - N-terminally truncated phosducin and beta-adrenergic receptor kinase $\mathrm{C}$ terminus (betaARKct) - in heart failure. Gene Ther 10:1354-1361. doi:10.1038/sj.gt.3301995

53. Lin Y, Smrcka AV (2011) Understanding molecular recognition by $\mathrm{G}$ protein subunits on the path to pharmacological targeting. Mol Pharmacol 80:551-557. doi:10.1124/mol.111.073072

54. Liu SJ (2007) Inhibition of L-type $\mathrm{Ca}^{2+}$ channel current and negative inotropy induced by arachidonic acid in adult rat ventricular myocytes. Am J Physiol Cell Physiol 293:C1594C1604. doi:10.1152/ajpcell.00284.2007

55. Madden MC, Wolkowicz PE, Pohost GM, McMillin JB, Pike MM (1995) Acylcarnitine accumulation does not correlate with reperfusion recovery in palmitate-perfused rat hearts. Am J Physiol 268:H2505-H2512

56. Mainland JD, Keller A, Li YR, Zhou T, Trimmer C, Snyder LL, Moberly AH, Adipietro KA, Liu WLL, Zhuang H, Zhan S, Lee SS, Lin A, Matsunami H (2014) The missense of smell: functional variability in the human odorant receptor repertoire. Nat Neurosci 17:114-120. doi:10.1038/nn.3598

57. Mamas MA, Terrar DA (2001) Actions of arachidonic acid on contractions and associated electrical activity in guinea-pig isolated ventricular myocytes. Exp Physiol 86:437-449. doi:10. 1113/eph8602252

58. Manteniotis S, Wojcik S, Brauhoff P, Möllmann M, Petersen L, Göthert JR, Schmiegel W, Dührsen U, Gisselmann G, Hatt H (2016) Functional characterization of the ectopically expressed olfactory receptor 2AT4 in human myelogenous leukemia. Cell Death Discov. doi:10.1038/cddiscovery.2015.70

59. Massberg D, Jovancevic N, Offermann A, Simon A, Baniahmad A, Perner S, Pungsrinont T, Luko K, Philippou S, Ubrig B, Heiland M, Weber L, Altmuller J, Becker C, Gisselmann G, Gelis L, Hatt H (2016) The activation of OR51E1 causes growth suppression of human prostate cancer cells. Oncotarget. doi:10. 18632/oncotarget.10197

60. Maßberg D, Simon A, Häussinger D, Keitel V, Gisselmann G, Conrad H, Hatt H (2015) Monoterpene (-)-citronellal affects hepatocarcinoma cell signaling via an olfactory receptor. Arch Biochem Biophys 566:100-109. doi:10.1016/j.abb.2014. 12.004 
61. Milligan G, Ulven T, Murdoch H, Hudson BD (2014) G-proteincoupled receptors for free fatty acids: nutritional and therapeutic targets. Br J Nutr 111:S3-S7. doi:10.1017/S0007114513002249

62. Mombaerts P (2004) Genes and ligands for odorant, vomeronasal and taste receptors. Nat Rev Neurosci 5:263-278. doi:10. 1038/nrn 1365

63. Montessuit C, Papageorgiou I, Tardy-Cantalupi I, RosenblattVelin N, Lerch R (2000) Postischemic recovery of heart metabolism and function: role of mitochondrial fatty acid transfer. J Appl Physiol 1985 89:111-119

64. Naga Prasad SV, Esposito G, Mao L, Koch WJ, Rockman HA (2000) Gbetagamma-dependent phosphoinositide 3-kinase activation in hearts with in vivo pressure overload hypertrophy. J Biol Chem 275:4693-4698. doi:10.1074/jbc.275.7.4693

65. Nakamura T, Gold GH (1987) A cyclic nucleotide-gated conductance in olfactory receptor cilia. Nature 325:442-444. doi: $10.1038 / 325442 \mathrm{a} 0$

66. Nekrasova E, Sosinskaya A, Natochin M, Lancet D, Gat U (1996) Overexpression, solubilization and purification of rat and human olfactory receptors. Eur J Biochem 238:28-37. doi:10. 1111/j.1432-1033.1996.0028q.x

67. Neuhaus EM, Zhang W, Gelis L, Deng Y, Noldus J, Hatt H (2009) Activation of an olfactory receptor inhibits proliferation of prostate cancer cells. J Biol Chem 284:16218-16225. doi:10. 1074/jbc.M109.012096

68. Offermanns S (2014) Free fatty acid (FFA) and hydroxy carboxylic acid (HCA) receptors. Annu Rev Pharmacol Toxicol 54:407-434. doi:10.1146/annurev-pharmtox-011613-135945

69. Parisi V, Rengo G, Perrone-Filardi P, Pagano G, Femminella GD, Paolillo S, Petraglia L, Gambino G, Caruso A, Grimaldi MG, Baldascino F, Nolano M, Elia A, Cannavo A, Bellis AD, Coscioni E, Pellegrino T, Cuocolo A, Ferrara N, Leosco D (2016) Increased epicardial adipose tissue volume correlates with cardiac sympathetic denervation in patients with heart failure. Circ Res 118:1244-1253. doi:10.1161/CIRCRESAHA. 115.307765

70. Parmentier M, Libert F, Schurmans S, Schiffmann S, Lefort A, Eggerickx D, Ledent C, Mollereau C, Gerard C, Perret J (1992) Expression of members of the putative olfactory receptor gene family in mammalian germ cells. Nature 355:453-455. doi:10. 1038/355453a0

71. Passier R, Oostwaard DW, Snapper J, Kloots J, Hassink RJ, Kuijk E, Roelen B, de la Riviere AB, Mummery C (2005) Increased cardiomyocyte differentiation from human embryonic stem cells in serum-free cultures. Stem Cells 23:772-780. doi:10.1634/stemcells.2004-0184

72. Petit-Jacques J, Hartzell HC (1996) Effect of arachidonic acid on the L-type calcium current in frog cardiac myocytes. J Physiol 493:67-81. doi:10.1113/jphysiol.1996.sp021365

73. Pezeshkian M, Mahtabipour M (2013) Epicardial and subcutaneous adipose tissue Fatty acids profiles in diabetic and nondiabetic patients candidate for coronary artery bypass graft. Bioimpacts 3:83-89. doi:10.5681/bi.2013.004

74. Pitcher JA, Inglese J, Higgins JB, Arriza JL, Casey PJ, Kim C, Benovic JL, Kwatra MM, Caron MG, Lefkowitz RJ (1992) Role of beta gamma subunits of $\mathrm{G}$ proteins in targeting the betaadrenergic receptor kinase to membrane-bound receptors. Science 257:1264-1267

75. Pluznick JL, Protzko RJ, Gevorgyan H, Peterlin Z, Sipos A, Han J, Brunet I, Wan L, Rey F, Wang T, Firestein SJ, Yanagisawa M, Gordon JI, Eichmann A, Peti-Peterdi J, Caplan MJ (2013) Olfactory receptor responding to gut microbiota-derived signals plays a role in renin secretion and blood pressure regulation. Proc Natl Acad Sci USA 110:4410-4415. doi:10.1073/pnas. 1215927110
76. Rask-Andersen M, Almén MS, Schiöth HB (2011) Trends in the exploitation of novel drug targets. Nat Rev Drug Discov 10:579-590. doi:10.1038/nrd3478

77. Reubinoff BE, Pera MF, Fong CY, Trounson A, Bongso A (2000) Embryonic stem cell lines from human blastocysts: somatic differentiation in vitro. Nat Biotechnol 18:399-404. doi:10.1038/74447

78. Rockman HA, Koch WJ, Lefkowitz RJ (2002) Seven-transmembrane-spanning receptors and heart function. Nature 415:206-212. doi:10.1038/415206a

79. Rodriguez M, Luo W, Weng J, Zeng L, Yi Z, Siwko S, Liu M (2014) PSGR promotes prostatic intraepithelial neoplasia and prostate cancer xenograft growth through NF- $\kappa \mathrm{B}$. Oncogenesis 3:e114. doi:10.1038/oncsis.2014.29

80. Saito H, Chi Q, Zhuang H, Matsunami H, Mainland JD (2009) Odor coding by a Mammalian receptor repertoire. Sci Signal 2:ra9. doi:10.1126/scisignal.2000016

81. Saito H, Kubota M, Roberts RW, Chi Q, Matsunami H (2004) RTP family members induce functional expression of mammalian odorant receptors. Cell 119:679-691. doi:10.1016/j.cell. 2004.11.021

82. Sanz G, Leray I, Dewaele A, Sobilo J, Lerondel S, Bouet S, Grébert D, Monnerie R, Pajot-Augy E, Mir LM (2014) Promotion of cancer cell invasiveness and metastasis emergence caused by olfactory receptor stimulation. PLoS One 9:e85110. doi:10.1371/journal.pone.0085110

83. Sato PY, Chuprun JK, Schwartz M, Koch WJ (2015) The evolving impact of g protein-coupled receptor kinases in cardiac health and disease. Physiol Rev 95:377-404. doi:10.1152/phys rev.00015.2014

84. Scholz P, Mohrhardt J, Jansen F, Kalbe B, Haering C, Klasen K, Hatt H, Osterloh S (2016) Identification of a novel gnao-mediated alternate olfactory signaling pathway in murine OSNs. Front Cell Neurosci 10:63. doi:10.3389/fncel.2016.00063

85. Shah AS, White DC, Emani S, Kypson AP, Lilly RE, Wilson K, Glower DD, Lefkowitz RJ, Koch W (2001) In vivo ventricular gene delivery of a beta-adrenergic receptor kinase inhibitor to the failing heart reverses cardiac dysfunction. Circulation 103:1311-1316. doi:10.1161/01.CIR.103.9.1311

86. Shepard BD, Cheval L, Peterlin Z, Firestein S, Koepsell H, Doucet A, Pluznick JL (2016) A renal olfactory receptor aids in kidney glucose handling. Sci Rep 6:35215. doi:10.1038/srep35215

87. Smrcka AV (2008) G protein $\beta \gamma$ subunits: central mediators of $G$ protein-coupled receptor signaling. Cell Mol Life Sci 65:2191-2214. doi:10.1007/s00018-008-8006-5

88. Smrcka AV, Lehmann DM, Dessal AL, Smrcka A, Lehmann D, Dessal A (2008) G protein betagamma subunits as targets for small molecule therapeutic development. Comb Chem High Throughput Screen 11:382-395. doi:10.2174/138620708784534761

89. Spehr J, Gelis L, Osterloh M, Oberland S, Hatt H, Spehr M, Neuhaus EM (2011) G protein-coupled receptor signaling via Src kinase induces endogenous human transient receptor potential vanilloid type 6 (TRPV6) channel activation. J Biol Chem 286:13184-13192. doi:10.1074/jbc.M110.183525

90. Spehr M, Gisselmann G, Poplawski A, Riffell JA, Wetzel CH, Zimmer RK, Hatt H (2003) Identification of a testicular odorant receptor mediating human sperm chemotaxis. Science 299:2054-2058. doi:10.1126/science.1080376

91. Suzuki M, Takaishi S, Nagasaki M, Onozawa Y, Iino I, Maeda H, Komai T, Oda T (2013) Medium-chain fatty acid-sensing receptor, GPR84, is a proinflammatory receptor. J Biol Chem 288:10684-10691. doi:10.1074/jbc.M112.420042

92. Synnergren J, Akesson K, Dahlenborg K, Vidarsson H, Améen C, Steel D, Lindahl A, Olsson B, Sartipy P (2008) Molecular signature of cardiomyocyte clusters derived from human 
embryonic stem cells. Stem Cells 26:1831-1840. doi:10.1634/ stemcells.2007-1033

93. Tikhonova IG, Poerio E (2015) Free fatty acid receptors: structural models and elucidation of ligand binding interactions. BMC Struct Biol 15:405. doi:10.1186/s12900-015-0044-2

94. Trapnell C, Pachter L, Salzberg SL (2009) TopHat: discovering splice junctions with RNA-Seq. Bioinformatics 25:1105-1111. doi:10.1093/bioinformatics/btp120

95. Trapnell C, Williams BA, Pertea G, Mortazavi A, Kwan G, van Baren MJ, Salzberg SL, Wold BJ, Pachter L (2010) Transcript assembly and quantification by RNA-Seq reveals unannotated transcripts and isoform switching during cell differentiation. Nat Biotechnol 28:511-515. doi:10.1038/nbt.1621

96. Ukhanov K, Brunert D, Corey EA, Ache BW (2011) Phosphoinositide 3-kinase-dependent antagonism in mammalian olfactory receptor neurons. J Neurosci 31:273-280. doi:10.1523/ JNEUROSCI.3698-10.2011

97. Ulven T (2012) Short-chain free fatty acid receptors FFA2/ GPR43 and FFA3/GPR41 as new potential therapeutic targets. Front Endocrin. doi:10.3389/fendo.2012.00111

98. Vanderhaeghen P, Schurmans S, Vassart G, Parmentier M (1997) Molecular cloning and chromosomal mapping of olfactory receptor genes expressed in the male germ line: evidence for their wide distribution in the human genome. Biochem Biophys Res Commun 237:283-287. doi:10.1006/bbrc.1997.7043

99. Veitinger T, Riffell JR, Veitinger S, Nascimento JM, Triller A, Chandsawangbhuwana C, Schwane K, Geerts A, Wunder F, Berns MW, Neuhaus EM, Zimmer RK, Spehr M, Hatt H (2011) Chemosensory $\mathrm{Ca}^{2+}$ dynamics correlate with diverse behavioral phenotypes in human sperm. J Biol Chem 286:17311-17325. doi:10.1074/jbc.M110.211524

100. Wade F, Espagne A, Persuy M, Vidic J, Monnerie R, Merola F, Pajot-Augy E, Sanz G (2011) Relationship between homooligomerization of a mammalian olfactory receptor and its activation state demonstrated by bioluminescence resonance energy transfer. J Biol Chem 286:15252-15259. doi:10.1074/ jbc.M110.184580

101. Wang J, Weng J, Cai Y, Penland R, Liu M, Ittmann M (2006) The prostate-specific G-protein coupled receptors PSGR and PSGR2 are prostate cancer biomarkers that are complementary to alpha-methylacyl-CoA racemase. Prostate 66:847-857. doi:10.1002/pros.20389

102. Wang J, Wu X, Simonavicius N, Tian H, Ling L (2006) Medium-chain fatty acids as ligands for orphan $\mathrm{G}$ protein-coupled receptor GPR84. J Biol Chem 281:34457-34464. doi:10.1074/ jbc.M608019200

103. Wang X, Liang B, Skibsbye L, Olesen S, Grunnet M, Jespersen T (2013) GIRK channel activation via adenosine or muscarinic receptors has similar effects on rat atrial electrophysiology. J Cardiovasc Pharmacol 62:192-198. doi:10.1097/FJC. 0b013e3182965221

104. Weigle B, Fuessel S, Ebner R, Temme A, Schmitz M, Schwind S, Kiessling A, Rieger MA, Meye A, Bachmann M, Wirth MP, Rieber EP (2004) D-GPCR: a novel putative G protein-coupled receptor overexpressed in prostate cancer and prostate. Biochem Biophys Res Commun 322:239-249. doi:10.1016/j.bbrc.2004. 07.106
105. Weng J, Wang J, Hu X, Wang F, Ittmann M, Liu M (2006) PSGR2, a novel G-protein coupled receptor, is overexpressed in human prostate cancer. Int J Cancer 118:1471-1480. doi:10. 1002/ijc. 21527

106. Wobus AM, Wallukat G, Hescheler J, Wobus AM, Wallukat G, Hescheler J (1991) Pluripotent mouse embryonic stem cells are able to differentiate into cardiomyocytes expressing chronotropic responses to adrenergic and cholinergic agents and $\mathrm{Ca}^{2+}$ channel blockers. Differentiation 48:173-182. doi:10. 1111/j.1432-0436.1991.tb00255.x

107. Wolfrum U, Schmitt A (2000) Rhodopsin transport in the membrane of the connecting cilium of mammalian photoreceptor cells. Cell Motil Cytoskelet 46:95-107. doi:10.1002/ 1097-0169(200006)46:2<95:AID-CM2>3.0.CO;2-Q

108. Wu C, Jia Y, Lee JH, Kim Y, Sekharan S, Batista VS, Lee S (2015) Activation of OR1A1 suppresses PPAR- $\gamma$ expression by inducing HES- 1 in cultured hepatocytes. Int J Biochem Cell Biol 64:75-80. doi:10.1016/j.biocel.2015.03.008

109. Xia C, Ma W, Wang F, Sb Hua, Liu M (2001) Identification of a prostate-specific G-protein coupled receptor in prostate cancer. Oncogene 20:5903-5907. doi:10.1038/sj.onc.1204803

110. Xiao Y, Gomez AM, Morgan JP, Lederer WJ, Leaf A, Xiao YF, Gomez AM, Morgan JP, Leaf A, Xiao Y (1997) Suppression of voltage-gated L-type $\mathrm{Ca}^{2+}$ currents by polyunsaturated fatty acids in adult and neonatal rat ventricular myocytes. Proc Natl Acad Sci USA 94:4182-4187. doi:10.1073/pnas.94.8.4182

111. Xu LL, Sun C, Petrovics G, Makarem M, Furusato B, Zhang W, Sesterhenn IA, McLeod DG, Sun L, Moul JW, Srivastava S (2006) Quantitative expression profile of PSGR in prostate cancer. Prostate Cancer Prostatic Dis 9:56-61. doi:10.1038/sj. pcan. 4500836

112. Yu J, Vodyanik MA, Smuga-Otto K, Antosiewicz-Bourget J, Frane JL, Tian S, Nie J, Jonsdottir GA, Ruotti V, Stewart R, Slukvin II, Thomson JA (2007) Induced pluripotent stem cell lines derived from human somatic cells. Science 318:1917-1920. doi:10.1126/science. 1151526

113. Yu Y, de March CA, Ni MJ, Adipietro KA, Golebiowski J, Matsunami H, Ma M (2015) Responsiveness of G protein-coupled odorant receptors is partially attributed to the activation mechanism. Proc Natl Acad Sci USA 112:14966-14971. doi:10. 1073/pnas. 1517510112

114. Zhang X, Bedigian AV, Wang W, Eggert US (2012) G proteincoupled receptors participate in cytokinesis. Cytoskeleton (Hoboken) 69:810-818. doi:10.1002/cm.21055

115. Zhang X, de La Cruz O, Pinto JM, Nicolae D, Firestein S, Gilad $Y$ (2007) Characterizing the expression of the human olfactory receptor gene family using a novel DNA microarray. Genome Biol 8:R86. doi:10.1186/gb-2007-8-5-r86

116. Zhuang H, Matsunami H (2007) Synergism of accessory factors in functional expression of mammalian odorant receptors. J Biol Chem 282:15284-15293. doi:10.1074/jbc.M700386200

117. Zhuang H, Matsunami H (2008) Evaluating cell-surface expression and measuring activation of mammalian odorant receptors in heterologous cells. Nat Protoc 3:1402-1413. doi:10. 1038/nprot.2008.120 